\title{
DEGLACIATION OF THE DUNGIVEN BASIN, NORTH-WEST IRELAND
}

\author{
STEPHEN McCARRON
}

(Received 7 October 2013. Accepted 5 November 2013.)

\begin{abstract}
This paper describes glacigenic landforms and sediments occurring within the Dungiven Basin, north-west Ireland. It relates them to the pattern and timing of deglacial events within several sectors of the late Midlandian British-Irish Ice Sheet. The distribution, association and sedimentology of relatively well-preserved relict deglacial landforms are used in combination to reconstruct the nature and pattern of deglaciation in the region. An intricate pattern of ice-marginal and topographic control on the formation of glacially fed water bodies within the basin occurred during glacial down- and back-wastage toward icesource areas. The dominant ice masses in the basin retreated west and south-west toward the south Donegal Highlands and Omagh Basin regions (Derrynaflaw Morphostratigraphic Unit). During evacuation of the Dungiven Basin by these ice fronts, the easternmost valleys of the northern Sperrin Mountains were deglaciating south-eastward, in the direction of the Lough Neagh Basin (Banagher Morphostratigraphic Unit). A proglacial lake in the mid- to lower Roe Valley during initial stages of the Derrynaflaw Unit was caused by the impoundment of proglacial drainage by a lobe of Donegal ice occupying the Foyle Basin. Subsequent glaciolacustrine environments in the valleys of the northern Sperrin Mountains were created by the interaction of retreating ice margins with local topography. Local watersheds provided control of water-body elevations as ice margins retreated south and west toward ice-dispersal centres.
\end{abstract}

\section{Introduction}

\section{Topographic setting}

The Dungiven Basin is an area of hill and valley topography of $\sim 150 \mathrm{~km}^{2}$ in north-west Ireland, encompassing the most northern slopes, foothills and valleys of the Sperrin Mountains and the Faughan/Roe Valleys (Fig. 1). Topographically, it is composed principally of the east-west-oriented Dungiven Depression, from Claudy (Irish National Grid Reference: 254400, 407400) to Dungiven (269000, 409500), Co. Derry, and the south-northdraining valleys of the Faughan/Roe Rivers. The Loughermore uplands ( $\sim 400 \mathrm{~m}$ above sea level (ASL)) dominate the centre of the basin and separate the Dungiven Depression from the Foyle Basin and its estuary to the north. To the west, the Dungiven Basin is separated from the Foyle Valley lowlands by a north-west/south-east-oriented spine of high ground (up to $370 \mathrm{~m}$ ASL) comprising Crockdooish, Eglish and Slievekirk. To the south, the south-west/north-east-oriented, locally $>400 \mathrm{~m}$ deep, Glenelly and Owenkillew Valleys dissect the Sperrins uplands (678m ASL at most), separating the Dungiven Basin from the Omagh Basin.

The occurrence of glacigenic sediment exposures within the Dungiven Basin is essentially limited to infrequent shallow streamside sections and a relatively large number of quarry excavations in commercially valuable sand and gravel deposits. On the 


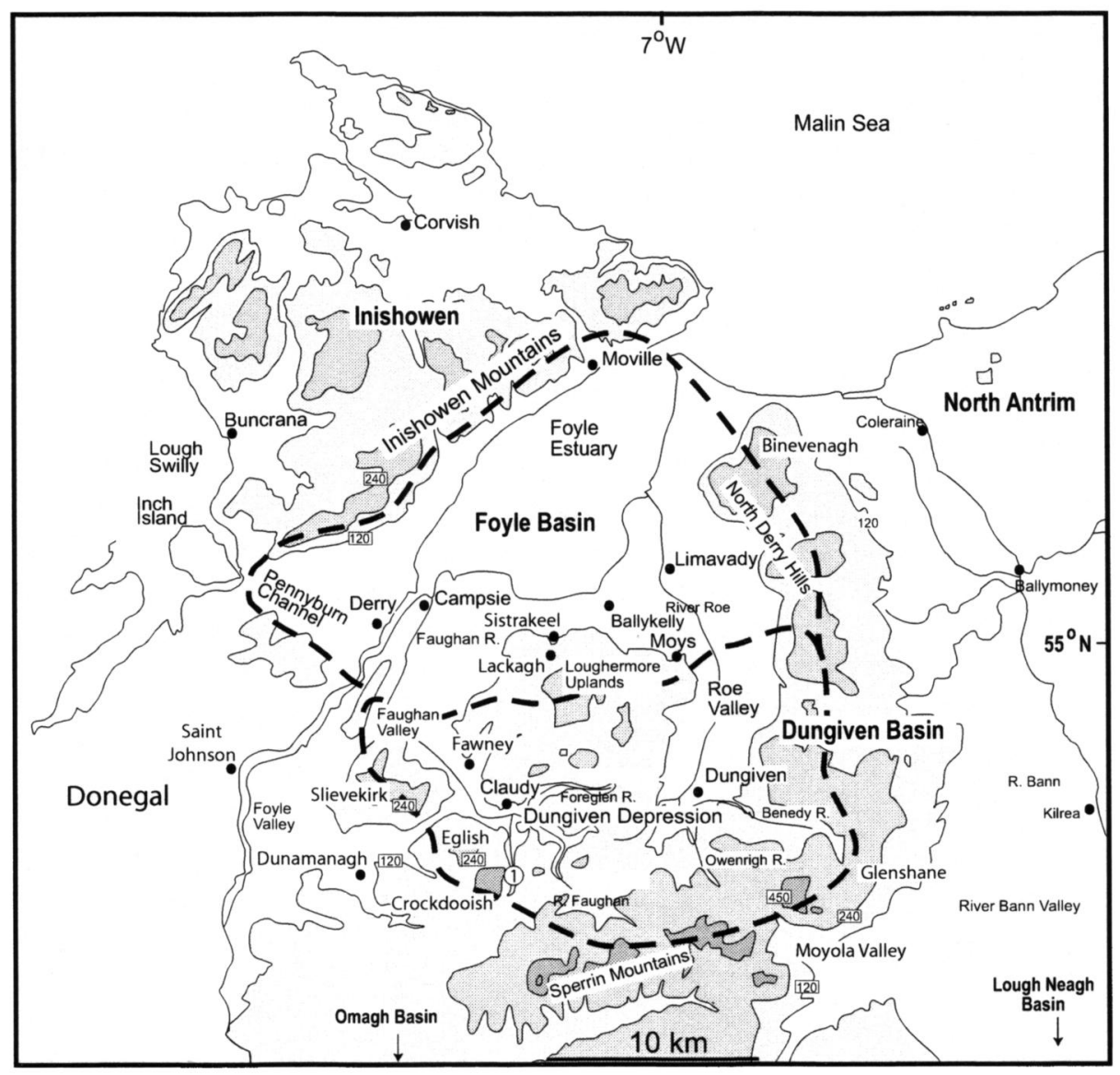

Fig. 1-Topography of the study area, Dungiven Basin, north-west Ireland.

upper flanks and summits of the Sperrins, Dalradian schist bedrock is commonly at or near the surface. Where exposed, sediment coverage there comprises a 1-2m smear of schist-dominated, relatively immature, massive angular diamict. Glacigenic sediments appear to thicken downslope and infill most topographic hollows on the mid- to upper hill slopes, adding to the generally smooth, rounded appearance of the upland region.

\section{Bedrock geology}

The low ground of the Dungiven Basin is predominately floored by Upper Dalradian pelitic and psammitic schistose lithologies, with Tournaisian Carboniferous occurring along the upper Roe Valley around Dungiven (Wilson 1972). A ridge of Argyll Group Dalradian facies forms the high ground of the Sperrin Mountains rising to the south. The North Derry Hills are capped by Palaeocene Upper Basalts, forming a scarped boundary to the east, from Binevenagh south to Benbradagh, near Dungiven.

\section{Previous work}

Traditional reconstructions of ice-sheet flow across the area during the principal period considered in this paper, the late Devensian Last Glacial Maximum (27-21ka BP, Chiverrell and Thomas 2010; 27-23ka BP, Clark et al. 2012), propose complete over-topping and inundation of the basin (Fig. 2). Models of the glacial history of the study area are based on a range of glacial geologic evidence, and in many cases ice flows across the region are inferred from palaeoglaciological models (e.g. Boulton et al. 1985; Warren 1992) based on evidence from elsewhere. The patterns of ice flow are based on dominant clast lithology (e.g. Colhoun 1970; Fig. 3); patterns of indicator erratic carriage, e.g. Cretaceous chalk, Ailsa Craig microgranite, Cushendun porphyry, Tardree rhyolite and Barnesmore granite (e.g. Dwerryhouse 1923; Charlesworth 1939; Colhoun 1970); and striae orientations and landform distributions, e.g. deglacial landforms (Dwerryhouse 1923), drumlin distributions and streamlined bedform 

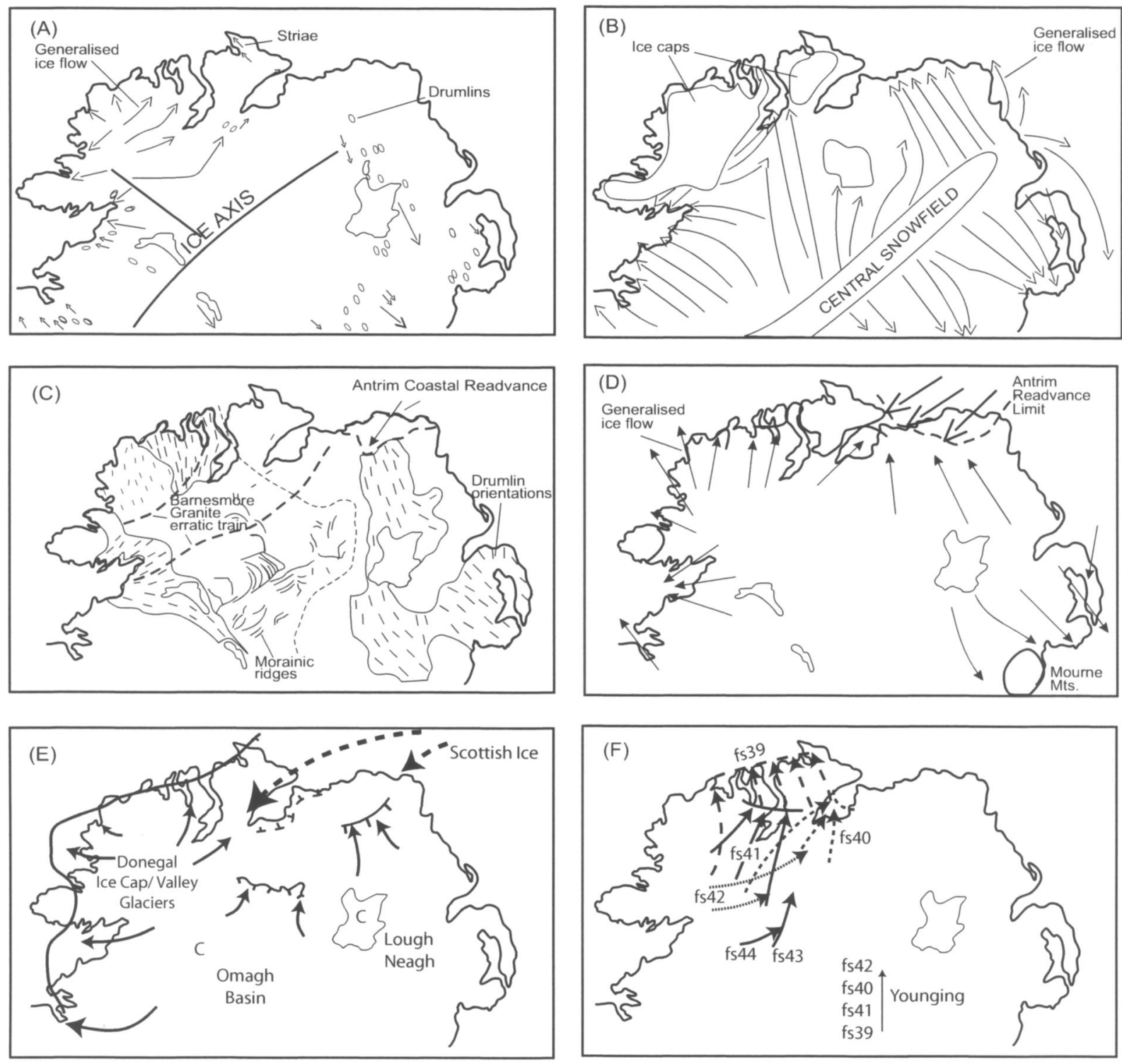

Fig. 2-Summary of previous models of glaciation in the north of Ireland. (A) Direction of ice dispersal (after Close 1866). (B) Direction of ice dispersal (after Hull 1891). (C) Ice movement and decay features (after Charlesworth 1924; 1939). (D) Late Devensian/ Midlandian ice movements (after Synge and Stephens 1960). (E) Generalised ice flows associated with the Killard Point Stadial; C = Ice dispersal centre (after McCabe et al. 1998). (F) Ice 'flowsets' in the last Irish Ice Sheet affecting the Foyle/Dungiven Basin (after Greenwood and Clark 2009).

long-axis orientations (e.g. Charlesworth 1939; Greenwood and Clark 2009).

A stratigraphy of two and possibly three 'tills' (Bazley et al. 1997) has been observed in restricted river-valley sections at Sistrakeel and Lackagh on the northern flanks of the Loughermore uplands (Fig. 1). Bazley et al. (1997) provide the only description of three 'tills' in the area, possibly attributed to three periods of glaciation (cf. Colhoun 1970). Their lower 'Lackagh Till' is described at one location (Lackagh) as light grey, micaceous, silty, non-calcareous clay containing clasts of striated Dalradian lithologies, derived from local sources. It is overlain by the lower 'till' of the Foyle and Dungiven Basins, which may be equivalent to the 'Lower Boulder Clay' of Wilkinson et al. (1908) and the chalk-bearing 'Bovevagh Till' of Colhoun (1971) (Fig. 3B). This diamict is described as a highly calcareous, light to medium grey (unweathered) and brown to chocolate-brown (weathered) clay containing chalk, limestone and flint erratics and detrital broken marine shells. The 

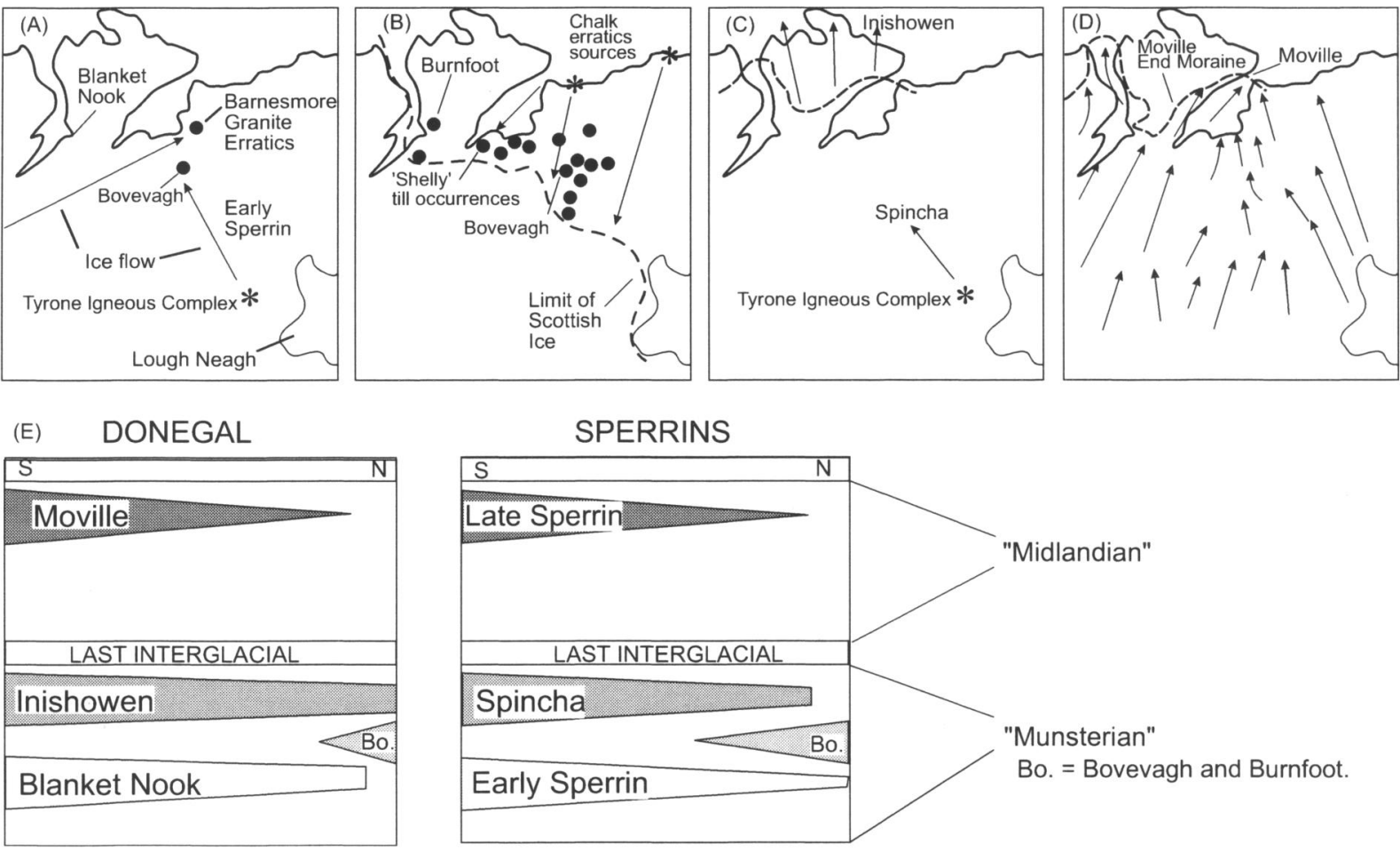

Fig. 3-Glaciations of the north of Ireland (after Colhoun 1970). (A) Blanket Nook and Early Sperrin. (B) Bovevagh and Burnfoot. (C) Inishowen and Spincha. (D) Late Sperrin. (E) Spatial and temporal correlations of glaciations in the north of Ireland (after Colhoun 1970; 1971).

erratics are all of a north-easterly source, with Cretaceous chalk cropping out in a narrow band along the base of the north-coast cliff line and the western flank of the North Derry Hills (Wilson 1972) (Fig. 3B). The detrital marine fauna are mostly bivalves but include crustacea and foraminifera (Wilkinson et al. 1908). The shell material is not believed to be in situ but glacially transported from offshore and deposited throughout the basin, reportedly at up to $240 \mathrm{~m}$ OD in the upper Gelvin River basin (Colhoun 1971). A glacigenic diamict (till) with these characteristics has traditionally been associated with an 'older' (Munsterian) glaciation of the basin by ice from the north or north-east (Scotland) (e.g. Kilroe 1888; 1913). Most models that include this phase of glaciation vary only in their detail of Scottish ice flow across the North Derry Hills.

A few attempts have been made to constrain the maximum age of the events responsible for redistribution of the shelly material in north County Derry by dating the shell fragments: i.e. the erosional event has to be younger than the youngest shell. At Sistrakeel, mollusc shells from massive, grey, clast-poor mud directly overlying a shelly, brown, basalt-rich diamict have yielded infinite
${ }^{14} \mathrm{C}$ ages of $>45 \mathrm{ka}$ BP (McCabe 1999). Bazley et al. (1997) also reported infinite ${ }^{14} \mathrm{C}$ ages from shells probably in the same strata and/or a nearby location.

Although largely outside the scope of this paper, the patchy distribution and exposure of 'older' sediments within the more northern parts of the Dungiven Basin, along the west-east line of the Loughermore uplands (e.g. Sistrakeel and Bovevagh, McCabe 1999), allows only a general evaluation of older glaciations in the region in terms of timing and provenance. It is inferred that the north of Ireland experienced at least one period of extensive glaciation during a pre-late Devensian cold stage. Based on the transport direction of Cretaceous chalk erratics south-westward from the northern and western lower slopes of Binevenagh into the lower Roe Valley, at least one of the glaciating ice masses was of Scottish provenance (Colhoun 1970; 1971) (Fig. 2).

\section{Models of late Devensian glaciation of the Dungiven Basin}

In traditional static 'snapshot' reconstructions of ice-flow patterns within the last British-Irish Ice 
Sheet (BIIS) at the Last Glacial Maximum (LGM) (Fig. 3), flow vectors across the western parts of the Dungiven Basin are generally inferred to have been derived from centres of ice dispersal in southern and central Donegal (Fig. 3D, E). Subsidiary ice flows are generally depicted as derived from centres of ice dispersal in the central/southern Sperrin Mountains and the Omagh and/or Lough Neagh Basins. Iceflow directions within and across the basin are generally not significantly influenced by the topography of the Sperrins, implying ice thicknesses significantly in excess of the local topographic range ( $\sim 400 \mathrm{~m}$ in the central Sperrins).

Traditional maximum ice limits in the north of Ireland at the LGM (e.g. McCabe 1987; Bowen et al. 1986) are generally accepted as extending to onshore limits on the peninsulas of northern Donegal and in the Bann Valley lowlands (Fig. 2D). More extensive ice flowsets across the north coast to offshore limits from source areas also in south and east Donegal are also modelled (e.g. Warren 1992; McCabe and Clark 2003; Greenwood and Clark 2009) (Fig. 2F).

Charlesworth (1924) (Fig. 2C) was first to propose a 'late-stage' glaciation of the Foyle and Dungiven Basins by ice from a centre of dispersal in the Donegal Highlands. Ice extents were reconstructed from the distribution of Barnesmore granite erratics (from the Blue Stack Mountains in south Donegal) across the region. The pattern of hypothesised bedrock-cut lake overflow channels and associated ice-marginal and extra-glacial lake basins in the Sperrins, Dungiven Basin and the eastern tributaries of the Foyle River supported a model of down- and back-wasting ice margins northward and southward across the spine of the Sperrins. In the Dungiven Basin, Charlesworth (1924) linked deposition of (some) glaciofluvial landforms with actively back-wasting Donegalsourced ice margins. Water bodies were ponded in proglacial troughs between the receding ice front and rising ground to the east (the Sperrins). This resulted in a suite of ice-marginal deltas that decreased in altitude northward and a complex pattern of glacial overflow channels controlling lake elevations. No evidence of palaeoflow indicators from within proposed lake infill sequences (deltas) is presented in the work, and a significant reinterpretation of many of the deposits is presented here.

Colhoun (1970; 1971) (Fig. 3) provided the most comprehensive investigations into the glacial geology of the central and northern Sperrins. He investigated both the glacial stratigraphy and the geomorphology of the region, using erratic carriage evidence, and reconstructed deglacial landform patterns to propose a set of at least three glacial advances into the Dungiven Basin from Donegal (Fig. 3A), Scotland (Fig. 3B), the Lough Neagh Basin/Sperrins (Fig. 3C) and the Omagh Basin (Fig. 3D). His model of LGM (his 'Late Sperrin') glaciation (Fig. 3D) was of complete inundation of the Dungiven Basin by ice principally sourced in the Omagh Basin. Notably, the deglaciation pattern of this stadial differs significantly from that of Charlesworth (1924), with the northern flanks of the Sperrins deglaciated from north to south by ice receding toward the Omagh Basin, not northward into the basin and then westward toward Donegal. The deglacial morphology presented in support of the model includes suites of back-stepping morainic limits and associated glaciofluvial terraces and meltwater-incised bedrock channels, formed as ice limits receded south into the Owenkillew Valley (south-west Sperrins).

Later workers in the region (e.g. Creighton 1974; Stephens et al. 1975) chose to largely omit the inclusion of deglacial features (e.g. glaciolacustrine landforms and sequences) as evidence of ice activity in the basin. They focused on interpreting the 'fresh drift' drumlin readvance limit of Synge and Stephens (1960) (Fig. 2D) as an LGM 'limit', placing it as far north as the southern slopes of Inishowen, on the north side of the Foyle Basin (cf. Colhoun's 'Late Sperrin' limit, Fig. 3D). Based on associated generalised south-north ice-flow indications, this LGM limit implied complete glaciation of the Dungiven Basin to the south. This limit within the Foyle Basin has been transferred to all succeeding interpretations of a late Devensian 'Drumlin Readvance'/LGM limit (e.g. McCabe 1987; Warren 1992).

The 'Killard Point Stadial' limit of McCabe et al. (1998) (Fig. 2E) was not associated with this limit, as it was in north-central Ireland (e.g. the Kells/ Dunany moraine). McCabe et al. (1998) proposed a late-stage glaciation of the Foyle Basin correlated with ice-sheet readvance in other sectors of the last BIIS during the Killard Point Stadial, < 14.2-13.7 ${ }^{14} \mathrm{C}$ ka BP (McCabe et al. 2007a). Ice was associated with a 'surging' lobe of Scottish ice crossing the North Channel and Malin Sea, part of a BIISwide response to climatic deterioration following Heinrich Event 1 in the wider North Atlantic (McCabe et al. 1998; 2007b; McCabe and Clark 1998; 2003).

Greenwood and Clark (2009) model late-stage (not specified but possibly post-LGM) ice flow from 
the south-west (central Donegal) to the Foyle Basin 'fresh drift' limit of Synge and Stephens (1960). They present flowsets based on 'ice-flow indicator' evidence comprising streamlined landform long axes and striae derived from digital elevation models and publications. The modelling reconstructs the superimposition of two sets of ice flows into the Foyle Basin (fs40 and fs41). If accurate, this was due, presumably, to a shift in ice-divide locations and/or changes in topographic control on ice flow during the lifetime of the last BIIS (Fig. 3F). The 'older' ice flow (f41) was north-north-eastward from southern Donegal (the Blue Stacks area, presumably), and it crossed the axis of the Foyle Valley lowlands obliquely toward Lough Swilly. A later flow (fs40) along the axis of the Foyle Valley from the same source region was directed more north-eastward, overprinting fs 41 in the Foyle Valley as ice flow converged toward the Foyle Estuary from Donegal and from within the Dungiven Basin. This flowset is modelled as crossing the southern shores of Lough Foyle north of the Loughermore uplands. The source of ice flow for the eastern parts of the earlier flowset (fs41) seems to have been an east-westoriented ice divide located along the northern flanks of the Sperrins (Greenwood and Clark 2009, fig. 11a), correlating well with the north-directed flows of Colhoun and others. The majority of the Dungiven Basin area is mapped as devoid of flowset indications, bar several generalised arrows in fs 40 . A later, smaller-scale flow (fs42), presumably associated with a smaller ice sheet, is reconstructed as occurring almost due eastward across the Foyle Valley from south Donegal toward the western flank of the Dungiven Basin.

\section{Questions addressed by this paper}

This paper attempts to place the formation of well-preserved glaciolacustrine landforms of the Dungiven Basin within a detailed regional reconstruction of last-BIIS ice-marginal retreat patterns. The information provided on the form and rate of deglaciation bridges a significant gap in knowledge between ice-sheet-flow indications based on geomorphic evidence alone (e.g. Greenwood and Clark 2009) and ice-sheet-event chronologies based on isolated landforms associated with other sectors of the last BIIS (McCabe et al. 1998).

The late Devensian lakes of the Dungiven Basin have been variously associated with either a readvance of Scottish ice margins into the Foyle Basin (McCabe et al. 1998) or more local mechanisms associated with a particular pattern of Irish icesheet-marginal retreat (Charlesworth 1924). In terms of palaeoglaciological information, these end-member interpretations invoke completely different associations between glaciofluvial sedimentation and ice-sheet dynamics. One model envisages the impoundment of a regional-scale water body that continued in existence during deglaciation of the basin by ice re-entering the valleys of the northern Sperrins (McCabe et al. 1998). The other envisages a pattern of small-scale, topographically defined, ice-marginal water bodies associated with down- and back-wasting north and south of the Sperrins (Charlesworth 1924).

Existing reconstructions of late Devensian glacial events in the Dungiven and Foyle Basins thus present a number of contrasting scenarios regarding the palaeoglaciology of several sectors within the last BIIS. Specifically, existing reconstructions of late-stage glaciation of the Foyle Basin differ in icesheet source area (Donegal or Scotland). The nature of retreat from the northern flanks of the Sperrins is also contrasted in models of northward backwasting of 'Donegal' ice (Charlesworth 1924) and southward recession of 'Omagh Basin' and 'Lough Neagh' ice (McCabe et al. 1998).

\section{Description of Morphostratigraphic Units}

Relatively well-preserved relict deglacial landforms, including glaciolacustrine deltas, outwash plains, moraines and esker fragments, occur in three main topographic settings: (1) in the Dungiven Depression (straddling the upper Roe and upper Faughan River catchments); (2) infilling the northern foothill valleys; and (3) as isolated deposits perched on generally north-facing flanks of the Sperrins.

The glaciofluvial deposits of the Dungiven Basin are grouped into two broad time-stratigraphic units using a morphostratigraphic approach that applies the principles of stratigraphy (e.g. Skinner and Porter 1987) to geomorphology and unconsolidated sediments (Lukas 2006). The two sets of landforms described here mainly consist of ice-marginal and extra-glacial glaciolacustrine deltas preserved at eleven principal locations in the basin (Fig. 4).

Co-ordinates supplied refer to the Irish National Grid.

\section{The Derrynaflaw Morphostratigraphic Unit}

The glaciodeltaic deposits of the Derrynaflaw Unit are described in chronostratigraphic order. Spatially, 


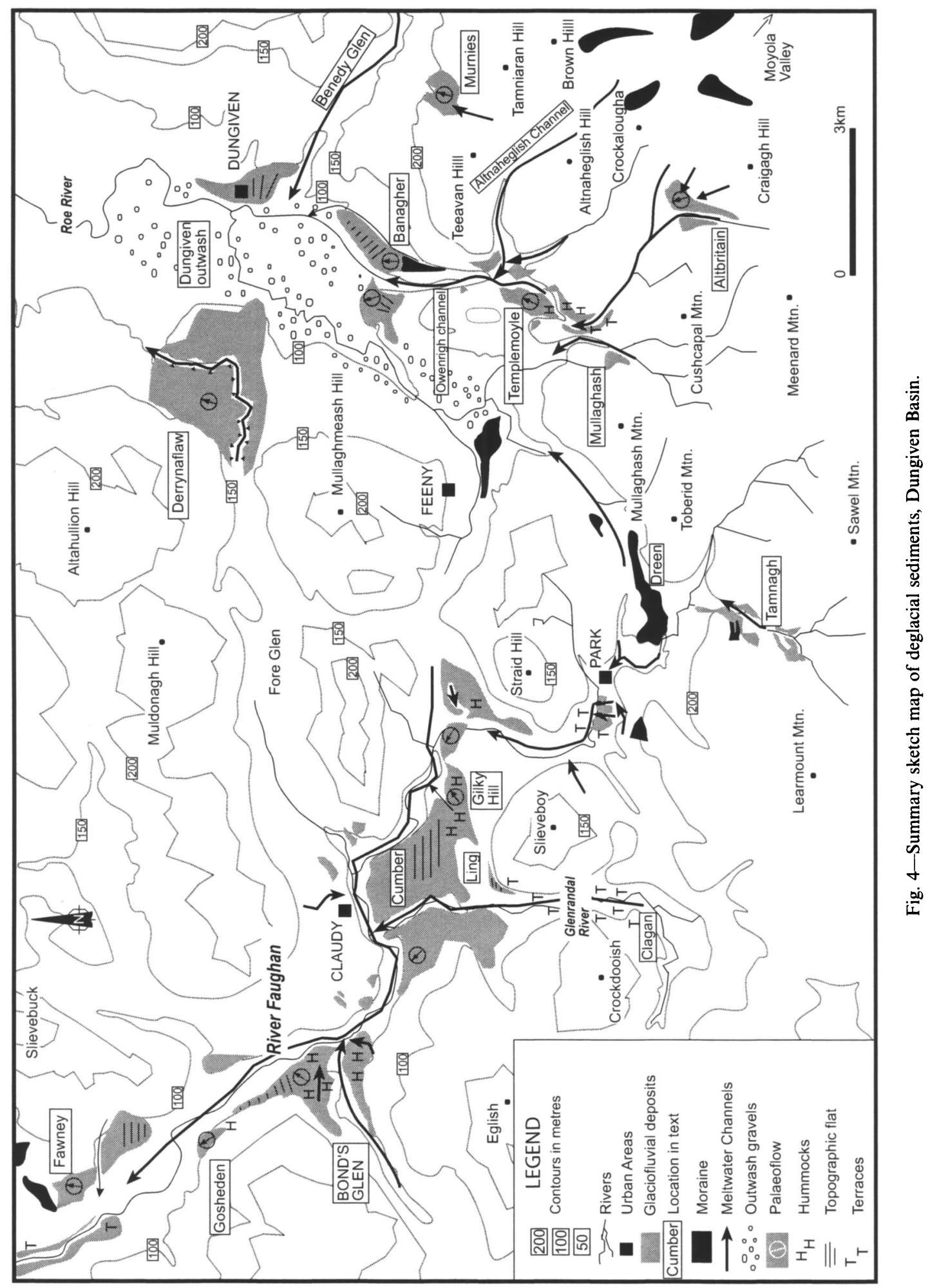


this unit forms a generally east-west trend across the Dungiven Basin, from the upper Roe Valley toward the upper Faughan Valley. A summary description of associated landforms, including morainic complexes, outwash plains and large-scale meltwater terraces, follows a description of the prominent glaciodeltaic landforms.

\section{Upper Faughan Valley deposits}

Derrynaflaw (265800, 409700)

Erosional remnants of a formerly more extensive sand and gravel landform comprise a $4 \mathrm{~km}^{2}$ asymmetric topographic high perched on the southeastern foot-slopes of Altahullion Hill. It occurs at the eastern end of the Fore Glen Depression, along the eastern margin of the topographic flat west of Dungiven, along the course of the modern Owenbeg River (Fig. 4).

The topography comprises a ridge at up to $\sim 142.5 \mathrm{~m}$ ASL that forms the southern margin of the deposit, from where it slopes north and northwest, generally along the trend of the Roe Valley (Fig. 5). The ridge is composed of extensively quarried north- and north-east-dipping (at $10^{\circ}$ to $30^{\circ} \mathrm{N}$ ), trough-cross-bedded sand and cobble-gravel deltaic foresets (Fig. 6). The deposit is dissected by the sinuous Altmover Glen channel, $3 \mathrm{~km}$ long and up to $40 \mathrm{~m}$ deep, on its north-western slopes. The channel intakes at $\sim 120 \mathrm{~m}$ ASL at the extreme western margin of the delta (at the eastern end of the Fore Glen Depression) and drains generally from south-west to north-east to $\sim 80 \mathrm{~m} \mathrm{ASL}$ in the Roe Valley.

\section{Interpretation}

The deposits at Derrynaflaw comprise remnants of a probably more extensive ice-contact glaciolacustrine subaqueous fan. The deposit occurs at the north-western margins of the Dungiven Depression, and palaeoflow data suggest that sediment supply was from this direction, with north/north-easterly progradation of the delta into a lake ponded in the upper Roe Valley to at least $142 \mathrm{~m}$ ASL. The deposit is inferred to be ice contact because it occurs as an isolated local topographic high, suggesting that an elevated sediment source must have been present to facilitate aggradation of the sediment body above the surrounding topography. The facies exposed are not indicative of typical subaqueous jet efflux

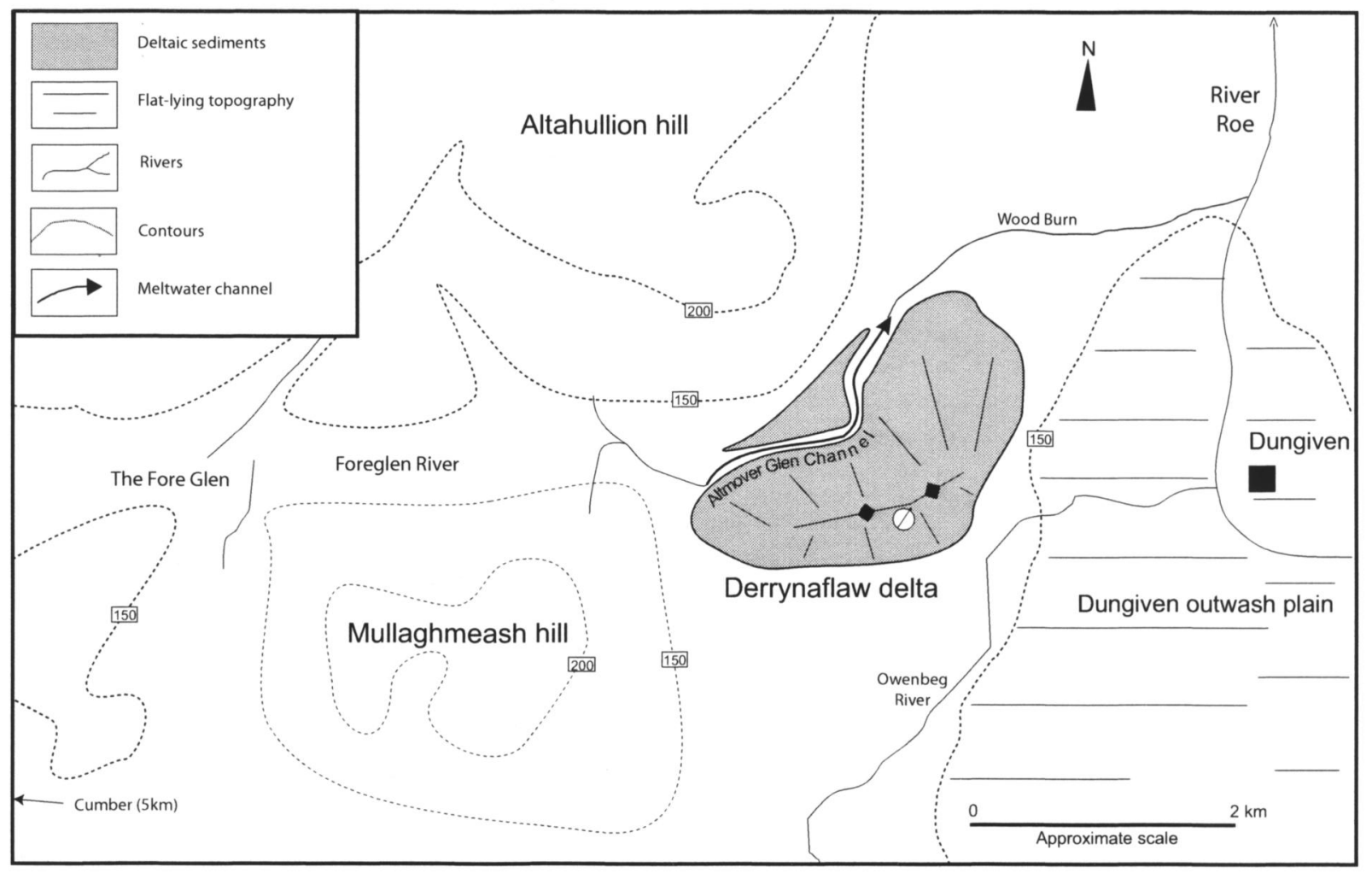

Fig. 5-Sketch map of Derrynaflaw delta area, Dungiven Basin. 


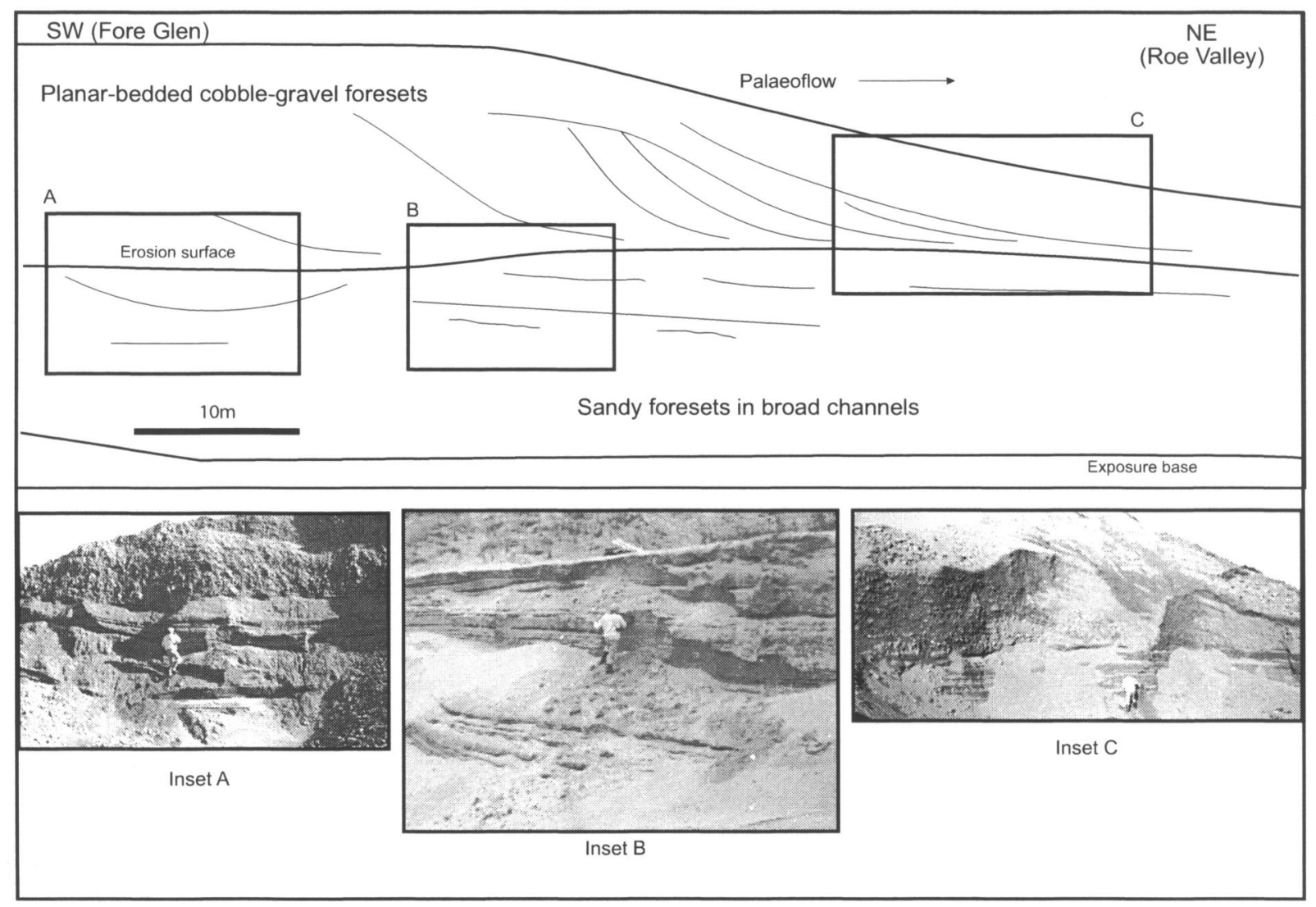

Fig. 6- Cartoon schematic longitudinal cross-section through Derrynaflaw foresets, Dungiven Basin.

deposits, which may aggrade to above the sediment source elevation because of high efflux hydrostatic water pressures. The facies exposed are interpreted as proximal parts of a low-angle subaqueous outwash fan (Rust 1988). Coarse-grained, poorly sorted ice-contact facies were not observed in exposures. Their absence may be due to post-depositional erosion of the previously more extensive fan on its southern margins, which border the Dungiven outwash plain. Post-depositional dissection has also occurred along the Altmover Glen channel. Meltwater originated from the direction of the Fore Glen Depression and indicates possible ice-marginal presence in this direction immediately post-dating subaerial exposure of the fan.

The formation of a subaqueous fan at this location requires the presence of a water-body surface at $>142 \mathrm{~m}$ ASL in the upper Roe Valley during relatively early stages of basin deglaciation. Possible mechanisms for this include: (1) inundation of the Foyle Basin and Roe Valley by high relative sea levels (HRSLs); (2) impoundment of a lake in the Roe Valley by (currently non-existent) sediments; (3) impoundment of a lake in the Roe Valley by a grounded ice margin in the lower Roe Valley/ Foyle Basin. Explanation (3) is the only one supported by any evidence, as subaqueous outwash deposits and ice-marginal topography at Moys (265957, 418358), on the southern margin of the Foyle Estuary, indicate the presence of an ice mass occupying the Foyle Basin during the late Devensian (McCarron 2000). The deposits at Moys aggraded to $\sim 120 \mathrm{~m} \mathrm{ASL}$, providing support for the presence of an ice margin across the lower Roe Valley impounding glacial meltwater to at least that elevation during at least the initial stages of Roe Valley deglaciation. No other location in the north of Ireland provides support for HRSLs at $>142 \mathrm{~m}$ ASL during deglaciation.

\section{Cumber (254350, 406200)}

Sand and gravel deposits at Cumber, in the upper Faughan Valley, consist of an extensive flat-topped steep-sided spread and associated hummocky 


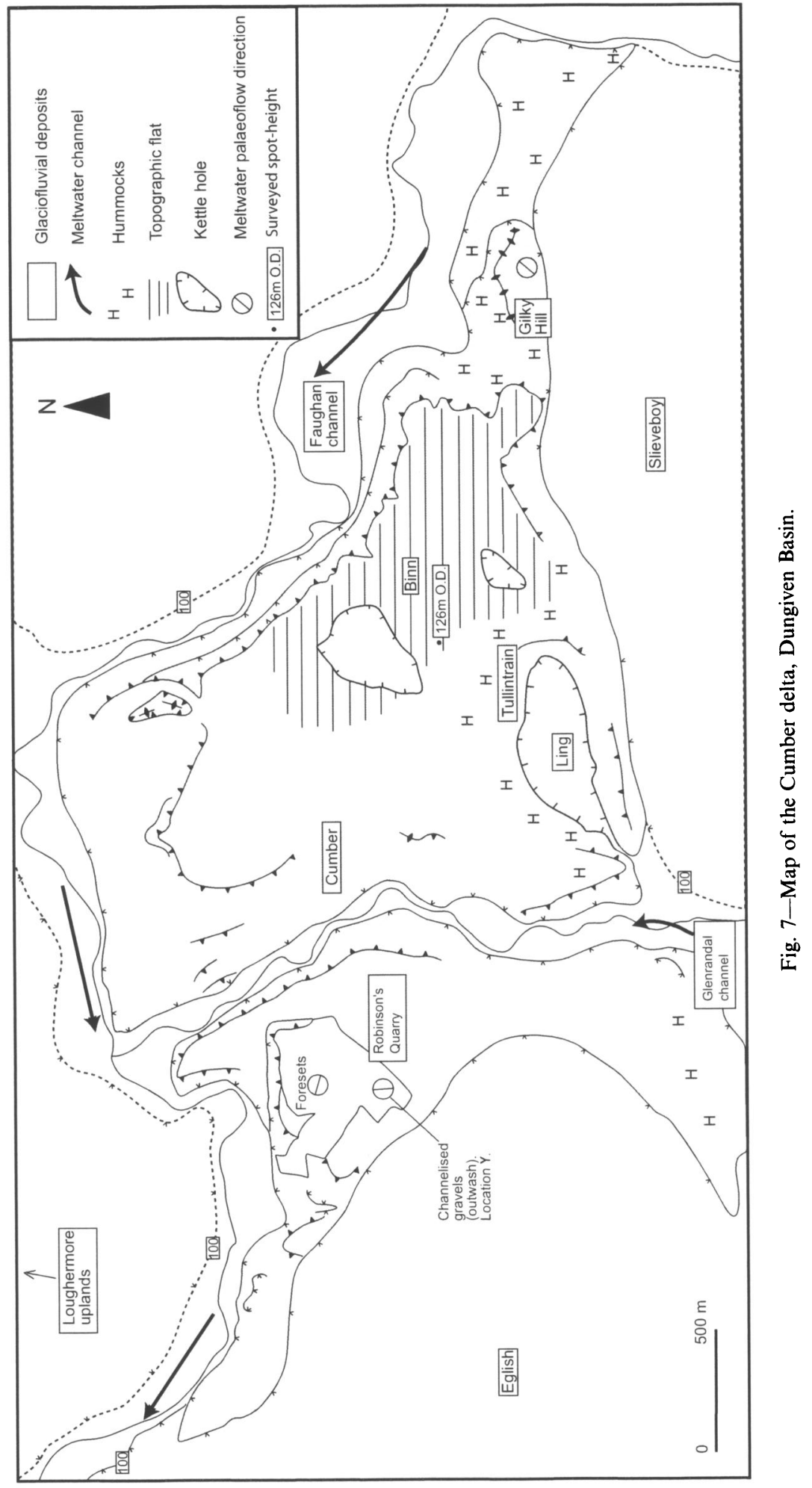


topography (Fig. 4). The deposits occur in the south-western corner of the Dungiven Basin, partially infilling the east-west-oriented topographic low of the Dungiven Depression. The foothills of the Sperrin Mountains rise rapidly to the south and west.

The spread slopes generally northward from a relatively flat and extensive plateau surface $\left(1.5 \mathrm{~km}^{2}\right)$ of low relief $(<5 \mathrm{~m})$ lying at $126 \mathrm{~m}$ ASL around Binn townland (Fig. 7). A 30m-deep, steep-sided meltwater channel containing the course of the presentday Glenrandal River separates the fragments. The deposit is also truncated on its northern and northeastern margins by steep erosional slopes of the upper Faughan River channel.

\section{Robinson's quarry (253500, 406200)}

An exposure logged at Robinson's quarry is located in the north-eastern corner of the flat-topped landform, north and downslope of the plateau (Fig. 7). The extensive ( $>100 \mathrm{~m}$ in total) section shows two lithofacies associations (LFAs): conformably bedded, well-sorted, planar and rippled sands in wide, shallow channels (S1), overlain unconformably by pebbly gravel sands (G1) (Figs 8 and 9). S1 consists of $1.4 \mathrm{~m}$ of conformably bedded, medium to fine sands contained in channels dipping at low angles $\left(<5^{\circ}\right)$. S1 contains beds showing both planar-horizontal and rippled lamination. The small-scale ripple sets $(<10 \mathrm{~cm}$ thick) consist of Atype, B-type and climbing forms (Jopling and Walker 1968) (Fig. 9, inset).

The succession of medium sands is truncated by a clearly defined erosion surface (Fig. 9, Point X). Above this discontinuity, $0.6 \mathrm{~m}$ of rippled and laminated pebbly sands are interbedded with small-scale $(<20 \mathrm{~cm}$ thick) gravel lags. These are conformably overlain by up to $10 \mathrm{~m}$ of planar-crossbedded sandy cobble gravel. The gravel beds dip at $20^{\circ}$ to the north.

At $50 \mathrm{~m}$ farther south in the quarry, $\sim 1.3 \mathrm{~m}$ of flat-lying, poorly sorted, massive cobble gravels (G2) occurs above an erosive contact with the planar-cross-bedded sandy cobble gravel (G1). G2 has little lateral extent owing to incision and removal by post-depositional erosion and quarrying.

In the south-western part of the quarry, poorly sorted pebble and cobble gravel occurs at the same elevation as $\mathrm{S} 1$ (Fig. 7, Location Y). The gravel is contained within multiple channels up to $20 \mathrm{~m}$ across and $8 \mathrm{~m}$ deep (Fig. 10). Internally, the channel fills consist of stacked beds of variably stratified pebble and cobble gravel, which show frequent textural variations. Beds are mainly massive, non-graded and bounded by sharp bed contacts, and they vary in thickness from $20 \mathrm{~cm}$ to $70 \mathrm{~cm}$. The upper $3 \mathrm{~m}$ of the sequence contains six large wedges of gravel, which truncate the primary gravel bedding (Fig. 10,

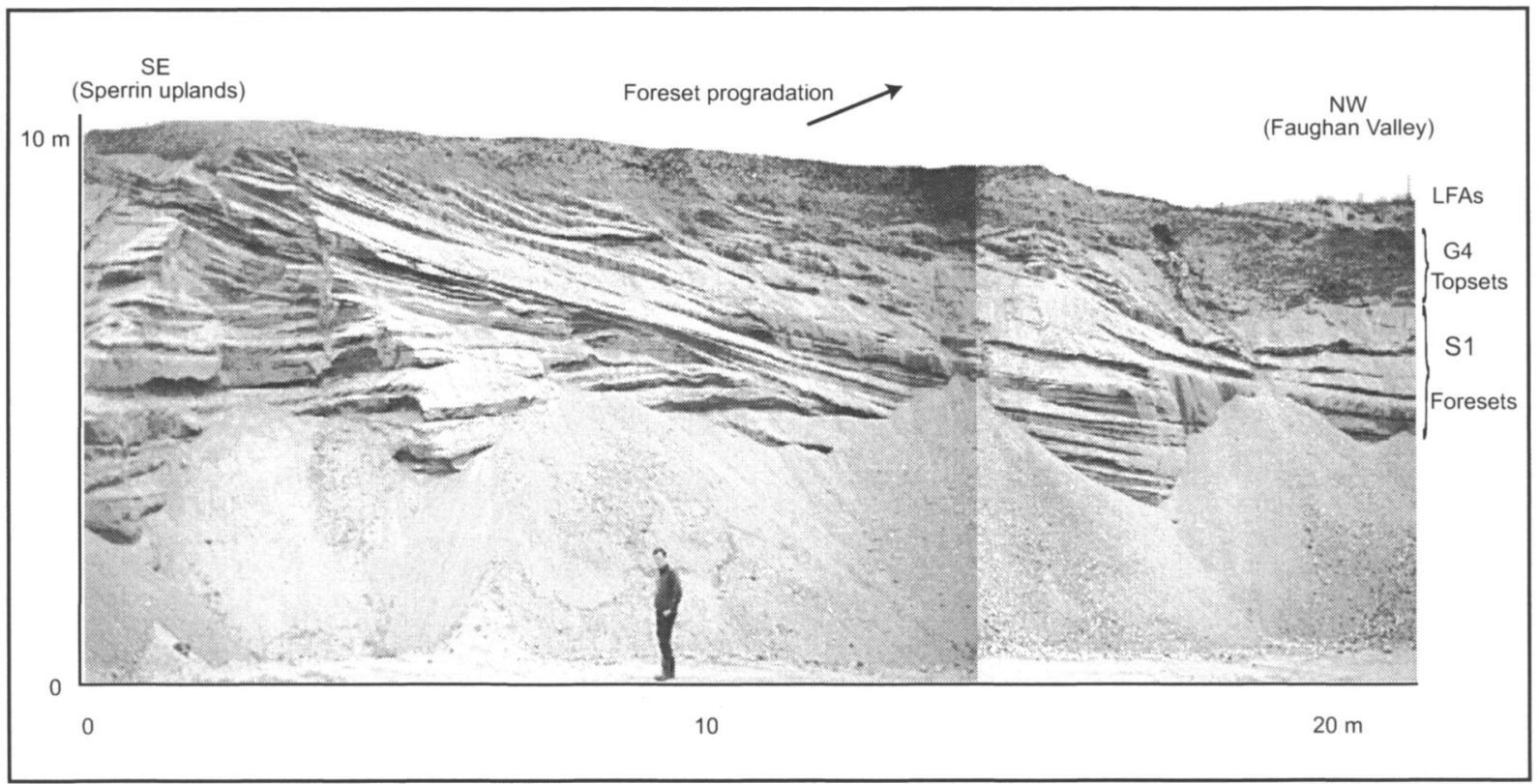

Fig. 8-Sandy foresets and gravel topsets, Robinson's quarry, Cumber delta, Dungiven Basin. 


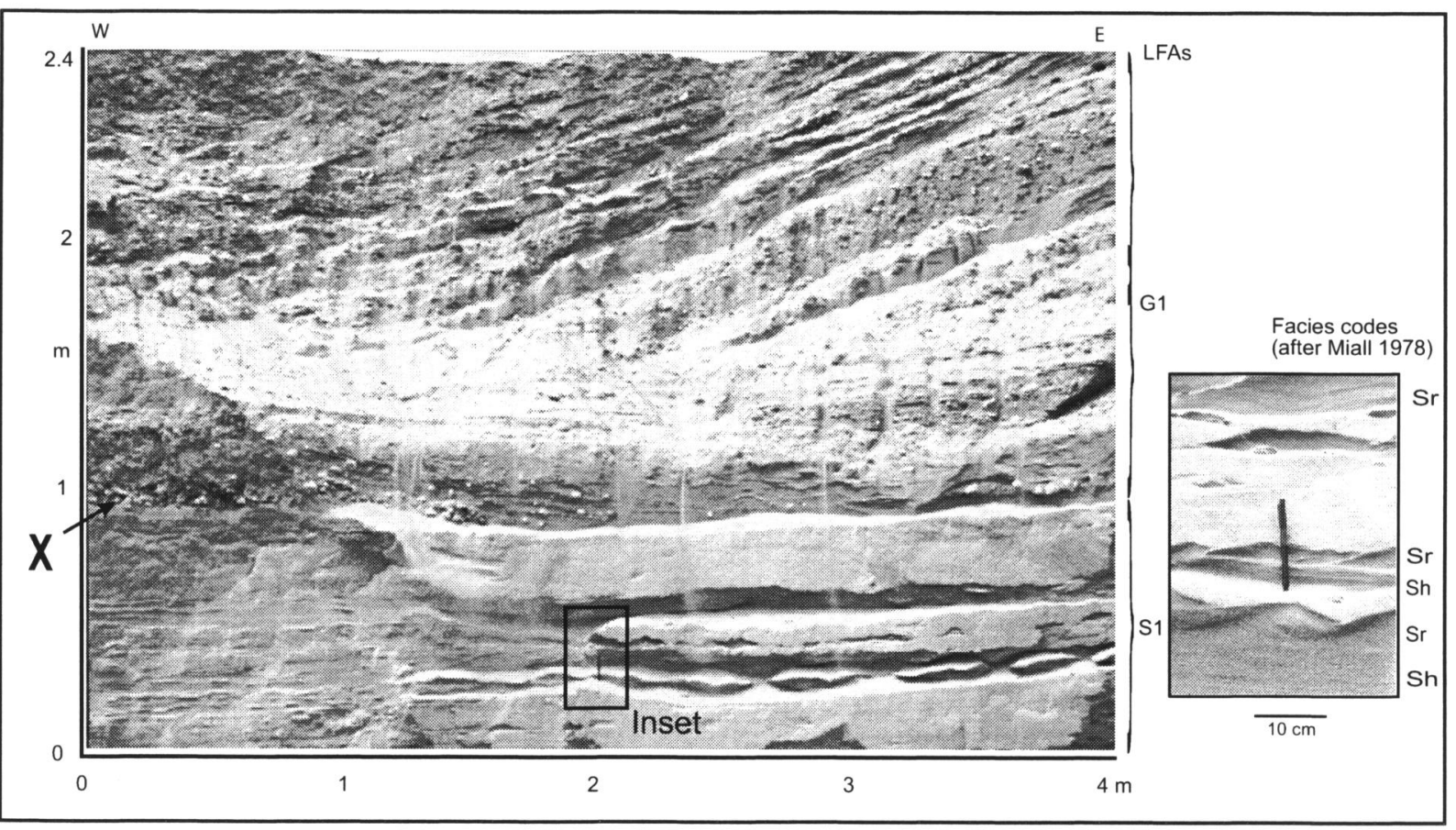

Fig. 9-Foreset lithofacies associations, Robinson's quarry, Cumber delta, Dungiven Basin.

Point X). These structures are up to $1.5 \mathrm{~m}$ across at the top and up to $5 \mathrm{~m}$ deep, tapering in width downwards.

\section{Tullintrain (255100, 404250)}

A $2 \mathrm{~km}^{2}$ area of small-scale hummocks, extensive hollows and dissected ridges adjoins the flat top at Binn $(255200,406300)$ to the south and south-east, extending south-east along the River Faughan channel. for $\sim 2.5 \mathrm{~km}$. Approximately $0.5 \mathrm{~km}^{2}$ of the area consists of low-amplitude hummocky topography comprising small-scale enclosed hollows in the spread's surface at Tullintrain, immediately south of and adjoining the plateau (Fig. 7). The small-scale hummocky topography is abruptly truncated on its southern margin by the steep slopes of a large-scale $\left(0.1 \mathrm{~km}^{2}\right)$ enclosed depression at Ling.

An exposure in the hummocky, dissected ridge complex, which extends east and south-east from Tullintrain along the southern margin of the

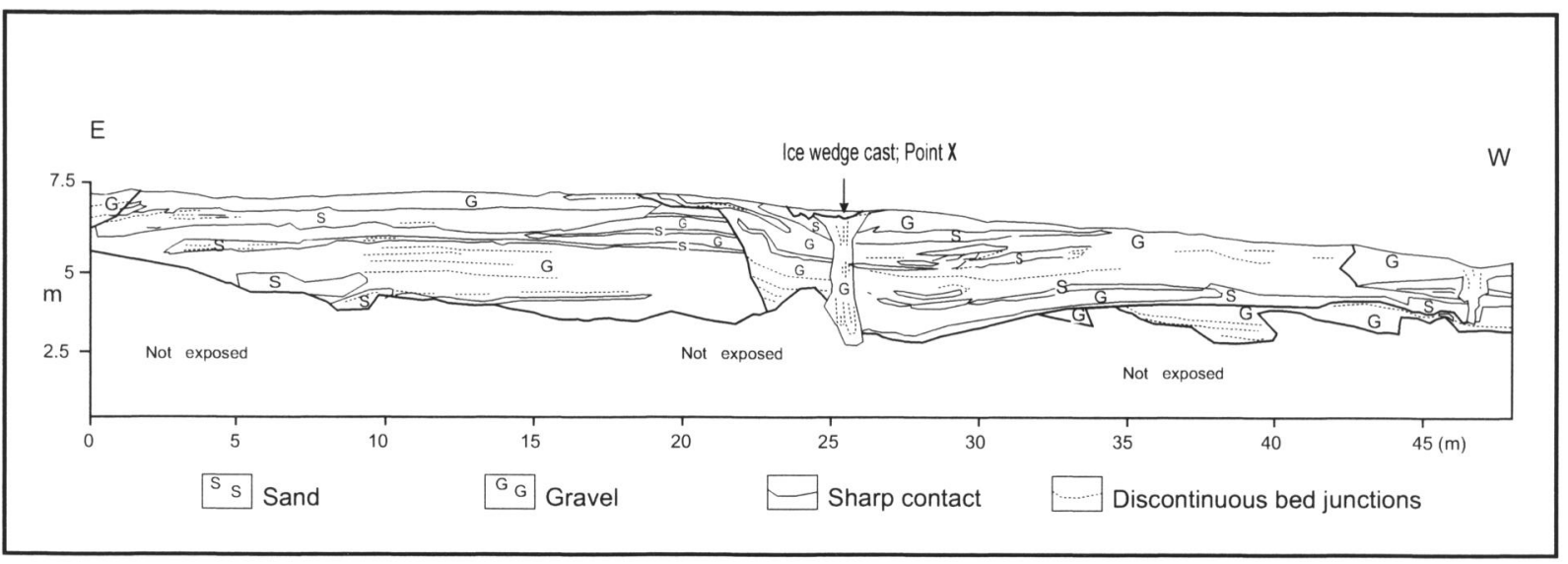

Fig. 10-Channelised gravels with ice wedge cast, Robinson's quarry, Dungiven Basin (Location Y, in Fig. 7). 
Faughan River, occurs in a commercial quarry at Gilky Hill (256900, 405400). Several facies of matrix-poor, channelised pebble and cobble gravel pass laterally into stacked units of planar-laminated and rippled sands contained within channels up to $10 \mathrm{~m}$ deep and $>25 \mathrm{~m}$ in diameter. The channel axes have an orientation of $040^{\circ}$, and dip at $<5^{\circ}$ to the north-east, away from the plateau area. An erosional contact separates both of these facies from flat-lying channel fills consisting of massive to crudely bedded gravelly sand. Both quarries have a similar pebble-clast composition of $49 \%$ schist and $49 \%$ vein quartz, with occasional erratics of quartz porphyry and granites $(<1 \%)$.

The valleys to the south of the spread (around Slieveboy Hill) are infilled with $\sim 2 \mathrm{~km}^{2}$ of gently north-sloping glaciofluvial terrace fragments. The terraces rise to the base of minor cross-valley morainic ridges around Clagan $(258600,404700)$.

\section{Interpretation}

The S1 facies at Tullintrain indicates a low-energy, subaqueous depositional environment, with sedimentation dominated by suspension rain-out of sand and traction-current reworking of beds into ripples. The undisturbed regular lamination of the sandy foresets indicates progradation into a deep proglacial water body. Progradation of sandy foresets occurred after flow separation on entrance into the water body. The sediments are interpreted as deltaic foresets. Consistent strikes and dips record sediment input from the south and east.

The steeper-angle, coarser sediments of G1 above the erosion surface indicate a switch of depositional environment into more competent, sediment-rich, higher-energy inputs into a subaqueous environment, demonstrated by the planar bedding. The coarser foreset beds represent a significant change in sediment-supply regime as the delta prograded or a change in the loci of the subglacial channels. Sediment supply changed to a higher-energy, coarser efflux that first eroded the existing topsets and foresets, before beginning to aggrade a new deltaic wedge.

The trough-cross-bedded cobble gravel (G2) overlying the sandy foresets is interpreted as topset beds formed in an avulsing, braided-stream-type proglacial environment during subaqueous deposition of G1. A reduction in water elevation would have exposed the delta surface to subaerial erosion by meltwater streams and the deposition of cut-andfill channelised gravel, i.e. G3.

\section{Upper Faughan Valley deposits: interpretation summary}

The sediments described at Robinson's pit and the surrounding area consist mainly of deltaic sequences associated with glaciofluvial outwash of sediments from active, but decaying, ice and their subsequent subaerial transport into ponded water bodies with surface elevations up to $126 \mathrm{~m}$ ASL. Foreset dips to the north and north-west indicate that sedimentation was associated with ice margins that were in the process of retreating generally south into the foothills of the Sperrin Mountains.

The extensive horizontal surface at Binn is inferred to be the intact depositional surface of Gilbert-type deltaic topsets. The area around Tullintrain, Ling and Gilky Hill, immediately south of the plateau, consists of coarser, increasingly iceproximal sediments (e.g. mounded gravel). Kettlehole formation in Binn townland (Fig. 7) indicates ice-block burial within the aggrading sediment pile and later topographic inversion upon melting, corroborating the ice-proximal setting. Thus the belt of hummocky topography may have been formed against an ice front (in ice contact). It thus possibly records the position of the ice margin during deposition of topset sediments (G2) also at Robinson's quarry, to the north-west, as the delta prograded north-westward as a low-angle spread, partially infilling the topographic low of the Dungiven Depression.

The sediments exposed at Robinson's quarry conform to classic models of glaciofluvial delta deposition near a subglacial efflux. The following model is proposed as the formative event sequence of the area's sediments:

1. As ice margins retreated south and west from the Dungiven Depression toward the south-western margins of the Sperrin Mountains, a glacial lake developed in the deglaciated area of the upper Faughan Valley. Drainage along the lower Faughan Valley must have been impeded at the time. The water body overflowed along the Fore Glen to the north-east, controlling waterbody height to $\sim 120 \mathrm{~m}$ ASL (Fig. 4).

2. Glaciofluvial outwash from effluxes in the direction of the Glenrandal and upper Faughan Valleys deposited gravel delta topsets and sandy glaciolacustrine foresets into the south-west of the lake. Shallow foreset dips $\left(10-20^{\circ}\right)$ represent lower-energy 
sediment gravity flows into the lake, indicating a more ice-distal location. Subaerial topset aggradation occurred to above water-body levels at $126 \mathrm{~m}$ ASL.

3. Sediment discharge occurred from at least two major sources, with increased meltwater discharges or delta lobe switching causing localised subaqueous erosion. Stacked delta foreset sequences indicate these slightly different palaeocurrent directions.

4. As water levels shallowed with sediment aggradation, subaerial exposure of the sediments resulted in the formation of cross-cutting channelised topset gravels.

5. Local stagnation of the ice front resulted in the burial of ice blocks and the formation of ice-contact topography along the southern margins of the deposit.

6. The delta's large-scale foresets record the former presence of an ice-marginal lake occupying the upper Faughan Valley as ice retreated generally toward the south-western parts of the Sperrin Mountains from the lowlands of the Dungiven Depression. Lake formation persisted until ice evacuated the mid- and lower Faughan Valley to the north.

7. After drainage, extensive dissection of the deltaic sands occurred by meltwater issuing northward along the Glenrandal and Faughan channels.

\section{Mid- to lower Faughan River Valley deposits}

Fawney. (249600, 412000)

An extensive $\left(\sim 2 \mathrm{~km}^{2}\right)$, flat-topped, bisected deposit occurs on the eastern flank of the middle Faughan Valley, between the Oaks and Fawney (Fig. 4). A $1 \mathrm{~km}^{2}$ flat top is well developed at the Oaks at $\sim 80 \mathrm{~m}$ ASL, where a $>30 \mathrm{~m}$-deep sediment wedge juts into the main channel of the Faughan Valley and laps onto the rising bedrock slopes of the Loughermore uplands to the east. The flat-topped wedge at the Oaks has an over-steepened southern (up-valley) margin. The Madam's Burn river now misfits a channel that intakes at the north-eastern margin of the flat top, at its junction with rising bedrock slopes to the east, bisecting the deposit into the Oaks and Fawney fragments.

At Fawney, the more northerly of the two fragments, a single poor exposure in the deposit occurs in a $0.75 \mathrm{~km}^{2}$. flat-topped to low-relief $(<5 \mathrm{~m})$ area infilling a south-east-sloping valley (deepening toward the Faughan Valley) on the south-eastern flank of the Loughermore uplands. The section shows large-scale trough-cross-bedded sand and pebble gravel in channels dipping at $<5^{\circ}$ to $20^{\circ}$ at the western (thickest) margin of the infill. On the lateral and north-western (upslope) margins, a locally 5-10m-high complex of hummocky ridge fragments partly encircles the valley infill. The hummocky sand and gravel ridges extend north to the head of the valley's drainage basin, where it forms the watershed with the steep-sided, rock-cut Muff Glen, which falls northward toward the Foyle Basin. At the mouth of the Muff Glen, along the southern margins of the Foyle Basin at Eglinton (252475, 420184), a low-angle spread of poorly draining, heavy topography falls gently and flattens northward (McCarron 2000).

\section{Interpretation}

The deposit is interpreted as an ice-marginal glaciolacustrine, Gilbert-type, flat-topped delta, formed as ice filled the Faughan Valley to the south. It is argued that the ice margin was located at the southern margins of the deposit, giving rise to the oversteepened (interpreted as ice-contact) up-valley slope. The sediments exposed at Fawney are interpreted as ice-distal facies deposited as the glaciolacustrine delta prograded northward and infilled pre-existing topographic lows in the flanks of the Faughan Valley. After drainage of the proglacial lake, meltwater flow from hillsides to the east dissected the deposit along the Madam's Burn channel.

Hummocky topography surrounding the infill at the Fawney deposit on its margins is interpreted as ice-marginal morainic deposits, pre-dating the deltaic deposit. It is inferred that the ice margin at this location retreated south and west from the flanks of the Loughermore uplands and its maximum extent in the Foyle Basin. As it retreated, temporary stillstands allowed the aggradation of lateral moraines while meltwater drained northward toward the Foyle Basin, eroding the Muff Glen channel. As the margin descended the flanks of the Faughan Valley, meltwater was impounded against the ice margin in the topographic low of the pre-glacial topography, allowing aggradation of the subaqueous spread. The spread was probably more extensive and has likely undergone post-depositional erosion after drainage of the valley along its western and northern margins. The eroded sediments were probably reworked into the extensive suites of glaciofluvial terraces that occur north of Fawney 
along the length of the lower Faughan Valley at Campsie (Fig. 1; McCarron 2000).

\section{Gosheden}

A small $\left(<0.2 \mathrm{~km}^{2}\right)$, perched, flat-topped terrace fragment occurs at $\sim 120 \mathrm{~m}$ ASL at Gosheden (250000, 409950), on the western flank of the $>60$ m-deep middle Faughan Valley (Fig. 4). The deposit is surrounded on its southern and southeastern margins by a belt of 5-10m-high gravel hummocks. An exposure near the flat-topped terrace crest exposes trough- and predominately planar-cross-bedded, well-sorted, openwork, steeply dipping $\left(25-30^{\circ}\right.$ to $\left.40^{\circ} \mathrm{N}\right)$ cobble gravel, sandy pebble gravel and normally graded, avalanche-front cobble gravel occurring in broad $(20-30 \mathrm{~m})$ channels (Fig. 11).

\section{Interpretation}

The terrace is interpreted as an ice-marginal glaciolacustrine deposit that prograded northward into a lateral water body impounded at $\sim 120 \mathrm{~m}$ ASL against the western slopes of the middle Faughan Valley. The deposit is alone at this elevation in this part of the valley. The steeply dipping channelised planar cross-beds and avalanche-front cross-strata are interpreted as high-angle foresets formed as part of subaqueous outwash infilling a valley-side lateral depression in the ice margin. The localised ice margin is demarcated by the hummocky morainic topography along the terrace's southern margins. The ice-marginal delta is inferred to have formed at approximately the same time as the larger Fawney delta, the dissected remains of which are located across the valley and to the north.

\section{Bond's Glen}

A large $\left(2 \mathrm{~km}^{2}\right.$ and $>30 \mathrm{~m}$-deep) belt of hummocky topography occurs at the eastern end (mouth) of Bond's Glen $(251150,407560)$ at up to $110 \mathrm{~m}$ ASL (Fig. 4). Bond's Glen forms a steep-sided, flatfloored, west-east-falling, >100m-deep, rock-cut

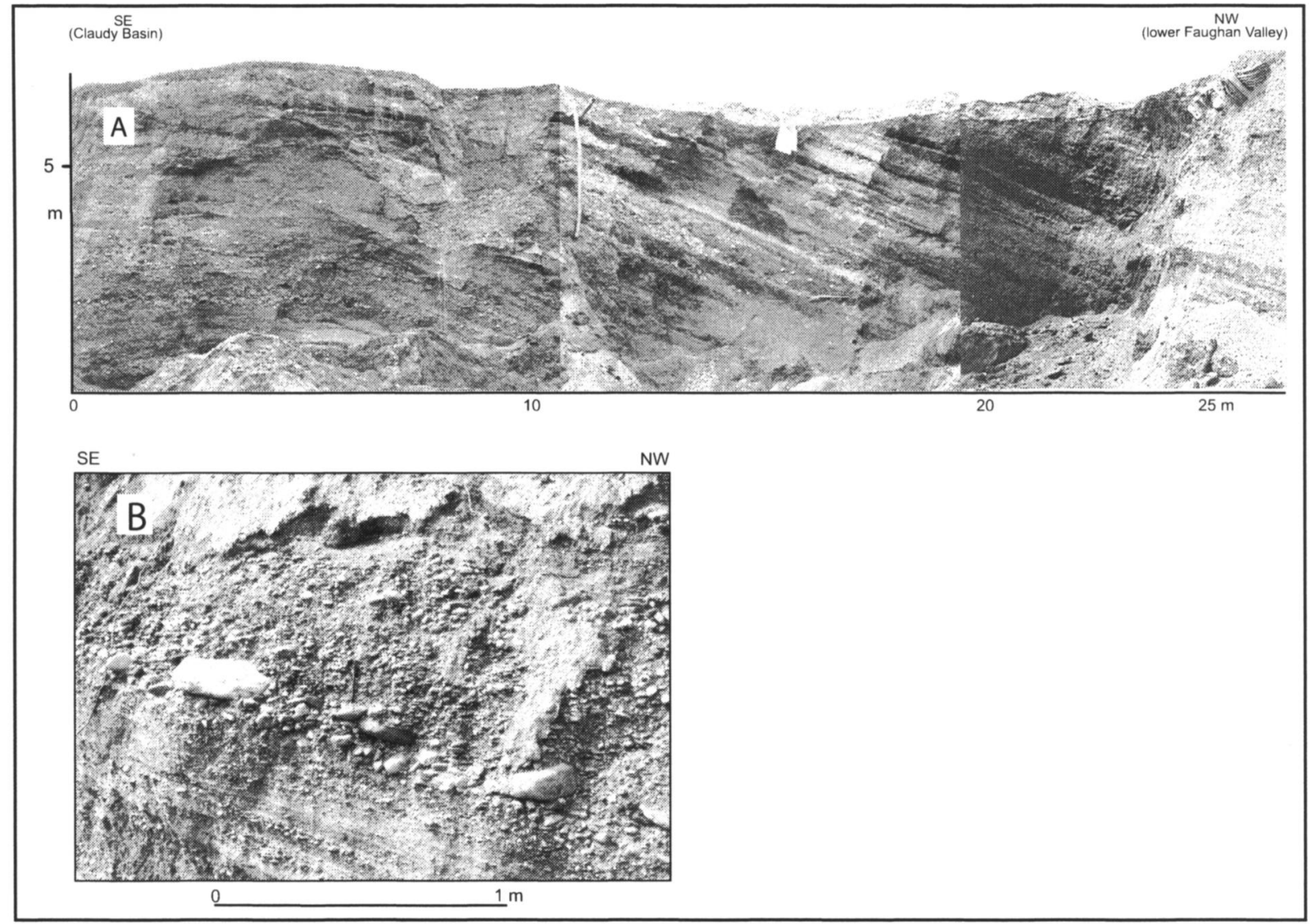

Fig. 11-Glaciofluvial deposits at Gosheden, Faughan Valley, Dungiven Basin. (A) Avalanche-front, cross-stratified (foreset) beds exposed at the crest of the valley-side remnant at Gosheden. (B) Detail of planar-bedded pebble gravel and normally graded, openwork, avalanche-front, cross-stratified gravel facies, Gosheden. Exposure near top of section, 10-15m south of (A). 
valley that links the middle Faughan Valley with the drainage basin of the Foyle Valley to the west. The hummocky belt has been extensively dissected by a central meltwater channel running along the centre of Bond's Glen and smaller channels that intake on the surface of the deposit. The smaller channels also drain eastward toward the Faughan Valley. To the north, along the western flank of the Faughan Valley, the hummocky belt abuts onto a $0.3 \mathrm{~km}^{2}$ flat-topped valley-side terrace that slopes gently north for $2 \mathrm{~km}$ at $\sim 90 \mathrm{~m}$ ASL. The formerly more extensive flat top has been dissected by the Faughan Valley channel and now occurs as two fragments on opposing sides of the Faughan channel.

\section{Interpretation}

The deposits at Bond's Glen represent a morainic belt and ice-marginal glaciolacustrine delta formed in the final stages of ice withdrawal into Bond's Glen from the middle Faughan Valley. The glaciolacustrine delta formed in a water body impounded in the middle and lower Faughan Valley. Deposition of the hummocky morainic complex followed drainage of the water body and retreat of the ice margin into the Bond's Glen valley. The ice margin is inferred to have been retreating toward the Foyle Valley to the west. Meltwater discharge along the Bond's Glen channel later dissected the morainic complex at the mouth (eastern end) of the valley.

\section{Faughan terraces}

Glaciofluvial deposits occur along the flanks of the middle and lower Faughan Valley in the form of extensive (10-12km-long and $<50 \mathrm{~m}$-thick), gently north-sloping, dissected sets of paired terrace fragments (Fig. 4). Two paired terrace levels are nested within the lower valley north of the Fawney delta, with the lower set terminating at the junction of the lower Faughan River with the Foyle Estuary at $\sim 20 \mathrm{~m}$ ASL around Campsie (Fig. 1).

\section{Interpretation}

The terraces are interpreted as dissected valley-fill outwash. The terraces formed after the opening of a free-drainage route northward along the middle and lower Faughan Valley and deposition from meltwater issuing from the drainage basin of the upper Faughan River and the Dungiven Depression. Falls in discharge and/or sediment yield resulted in dissection of an initial outwash plain, giving rise to higher and lower cross-valley terrace fragments. The lowest set within the Faughan Valley outwash system graded northward, possibly as thalossostatic terraces, into HRSLs of $\sim 20 \mathrm{~m}$ ASL in the Foyle Basin (McCarron 2000), probably in combination with changes in river discharge and sediment yield (Dawson and Gardiner 1987).

\section{Associated landforms: outwash plains, meltwater channels and glaciofluvial terraces}

In the area associated with deposits of the Derrynaflaw Formation, relating to ice-mass decay along the east-west-trending Dungiven Depression, several examples of outwash plains, moraines and largescale meltwater channels occur (Fig. 4). The flow direction of the meltwater channels is strongly dictated by regional topography.

East of the Dungiven Depression's watershed between Altahullion Hill, Mullaghmeash Hill, Umrycam Hill and Toberid Mountain, the valleys of the northern foothills of the Sperrin Mountains contain rock-cut meltwater channels that feed eastward toward the large ( $>20 \mathrm{~km}^{2}$ and $<5 \mathrm{~m}$-thick), undulating Dungiven outwash plain in the central lowlands of the upper Roe Valley. The northern margin of the outwash plain forms a sharp angular contact with the southern slopes of the Derrynaflaw delta. The process of the outwash plain's formation has probably resulted in truncation of the delta.

West of the drainage divide, channels fall generally north-westward along present river valleys toward the principal channel of the area now occupied by the misfit Faughan River (Fig. 4). In the higher reaches of the valleys, dissected sets of glaciofluvial terraces line the channel margins (e.g. in the upper Faughan River Valley, Glenrandal River Valley).

Several morainic belts line the meltwater channels (e.g. Clougherna channel, Altcattan channel) feeding eastward out of the Sperrin foothills. At Dreen and Feeny, cross-valley, hummocky and dissected morainic belts up to $15-20 \mathrm{~m}$ high probably mark the presence of former ice-marginal stillstands as ice retreated generally west along the valleys. Continued meltwater output accompanying further retreat later dissected these moraines, reworking the sediments into the Dungiven outwash plain, which originates and widens away from the mouths of the meltwater channels. 


\section{Interpretation of the Derrynaflaw Morphostratigraphic Unit}

The retreat pattern is principally constrained by subaqueous outwash deposits aggraded in the topographic low of the basin at four main locations: Derrynaflaw, Cumber, Fawney and Bond's Glen. The topology of the Derrynaflaw delta (northsloping) and the sedimentary architecture (southnorth-dipping foresets) indicate that deposition occurred from south-western sediment sources toward the centre of the Dungiven Depression. The north-prograding foresets and topsets in the glaciolacustrine delta at Cumber indicate the formation of a Gilbert-type delta at an ice margin located, and later retreating, toward the south.

The formation of a delta sequence in the middle Faughan Valley (Derrynaflaw delta) records icemass withdrawal from maximum extent somewhere to the north along the Roe Valley (toward the southern margins of the Foyle Basin). Ice occupying the middle Faughan retreated south and south-west toward the Bond's Glen valley. The fall of meltwater channels within the Dungiven Depression indicates drainage patterns largely consistent with today's, to the east in the eastern areas and the west in the western areas.

\section{Summary}

It is inferred from the morphology, sedimentology and spatial distribution of glaciofluvial deposits comprising the Derrynaflaw Unit that late Devensian deglaciation of the Dungiven Basin's lowland valleys proceeded toward the west/south-west (Fig. 15).

The extent of ice at the onset of deglaciation was to the east-north-east of the Derrynaflaw delta in the Roe Valley, but the exact location is not marked by prominent 'terminal' topographic expression. Models for the impoundment of ice-marginal water bodies to explain the Banagher Unit postulate extension of these ice margins as far east as the North Derry Hills. The ice-flow vectors thus had probable source to the south-west of the Sperrin Mountains, in the southern Donegal uplands and/or northern portions of the Omagh Basin.

In the later stages of ice retreat, the ice-marginal configuration was strongly controlled by the topography of the northern foothills of the Sperrin Mountains, probably producing valley glaciers separated by hills of $<150 \mathrm{~m}$ local relief. This probably occurred as the ice-marginal zone thinned with general ice-sheet down-wasting. It is inferred from the lack of a regionally extensive 'melt-out' diamict cover and/or indicative stagnation-zone retreat landforms (e.g. belts of hummocky moraine) that during deglaciation ice flow was relatively active, probably experiencing episodes of marginal still-stand and possibly readvance.

Water-body ponding mechanisms in the upper Roe Valley

The formation of a water body in the upper Roe Valley to the elevation of the Derrynaflaw delta top (142m ASL) requires water ponding to that elevation in the lower reaches of the Roe Valley. The damming mechanism may be related to the formation of ice-contact subaqueous outwash fan at Moys, on the north-eastern slopes of the Loughermore uplands in the lower Roe Valley (McCarron 2000) (Fig. 1). The glaciofluvial deposits at Moys form part of a semi-continuous belt of ridged glaciofluvial sediments extending west along the southern margins of the Foyle Estuary and are inferred to relate to sedimentation at the margin of an outlet glacier lobe occupying the Foyle Basin. It is inferred that the deposits at Moys and those of the Derrynaflaw Unit are approximately coeval, deposited into a water body with an upper surface of $>120 \mathrm{~m}$ ASL infilling the upper and lower Roe Valley. The impoundment mechanism is inferred to have comprised an ice mass occupying the Foyle Basin during the initial stages of Dungiven Basin deglaciation at least. An over-ice overflow channel or one located along the northern rim of Binevenagh (Fig. 1) possibly controlled waterbody elevation at $142 \mathrm{~m}$ ASL.

Water-body ponding mechanisms in the mid- to upper Faughan Valley

Deglaciation of the Faughan Valley proceeded from north to south along the valley, as recorded by a series of ice-marginal glaciolacustrine (Fawney and Gosheden) and morainic (Bond's Glen) deposits. The delta at Fawney, in the mid- to lower Faughan Valley, indicates that an ice-marginal lake at $\sim 80 \mathrm{~m}$ ASL was present along the eastern flank of the lower Faughan Valley, controlled by the Muff Glen channel to the north-west, which intakes at $\sim 80 \mathrm{~m}$ ASL. The Muff Glen channel empties northward into the Foyle Basin at Eglinton. This model may help to explain the presence of extensive raised valley-side terraces at up to $20 \mathrm{~m} \mathrm{ASL}$ in this area as 'bottomsets', formed by fines carried over into the Foyle Basin from the Faughan Valley during a period of HRSLs. 
Ice withdrawal is inferred to have continued southward along the middle Faughan Valley as far as the valley's junction with the deeply incised Bond's Glen. It is inferred that meltwater drainage along the Faughan Valley was blocked by ice issuing from this tributary valley, ponding water in the upper Faughan Valley. The deposition of the Cumber delta indicates that a deep ice-marginal glacial lake (glacial Lake Claudy) filled the topographic low of the upper Faughan Valley during at least some part of its deglaciation. Overflow from glacial Lake Claudy is inferred to have occurred farther east, around the flanks of Mullaghmeash Hill via the Fore Glen Depression and the Altcattan Glen channel. Lake overflow along the Fore Glen Depression may have resulted in the deep dissection of the Derrynaflaw delta along the Altmover Glen channel, which intakes at the eastern end of the Fore Glen at $\sim 120 \mathrm{~m}$ ASL and falls to the elevation of the Dungiven outwash plain in the middle Roe Valley. This model implies that the lower Roe Valley was ice-free at this time.

After deglaciation of the mid-Faughan Valley by ice issuing from Bond's Glen and opening of the Faughan Valley channel northward toward the Foyle Estuary, extensive dissection of glaciolacustrine deposits in the mid- to upper Faughan Valley by continued meltwater supply from southwarddeglaciating margins resulted in the formation of extensive glaciofluvial terraces along the lower flanks of the mid- and lower Faughan Valley. The lower reaches of these terraces possibly graded into HRSLs of $\sim 20 \mathrm{~m}$ ASL in the Foyle Basin. HRSLs of at least these values are recorded along the length of the basin eastward in the form of raised beach notches and a raised terrace at Fruitfield, Limavady.

\section{The Banagher Morphostratigraphic Unit}

The Banagher Unit consists of glaciofluvial and glaciodeltaic landforms and associated geomorphology in the northern flanks of the Sperrin Mountains (Fig. 2).

\section{The Murnies}

This glaciofluvial complex is perched on the northeast-facing, rounded bedrock slopes of the Benedy Glen, a north-draining deeply dissected valley up to $3 \mathrm{~km}$ wide in the northern face of the Sperrin Mountains (Fig. 4). The wedge-shaped deposit thickens north-eastward from the mouth of the $1 \mathrm{~km}$-long Altnaheglish bedrock meltwater channel, which intakes at $\sim 265 \mathrm{~m}$ ASL on the col between Tamniarin and Teeavan Hills (Fig. 12). The Murnies $(270400,405940)$ comprises two prominent, lobate, flat-topped surfaces at $230 \mathrm{~m}$ and $243 \mathrm{~m}$ ASL, which cover an area of $\sim 0.75 \mathrm{~km}^{2}$. The valley-facing northern and north-eastern slopes are steep (25$30^{\circ}$ ) and free of erosional scars. Small meltwater channels occur along the upper lateral margins of the deposit.

Internally, the deposit consists of two principal LFAs. About $90 \%$ of the deposit consists of largescale foresets of alternating sand and gravel beds that dip to the north-east. Clasts are predominately quartzite $(99 \%)$, with a small schist component $(1 \%)$. Foresets occur within broad channel-like structures.

An angular unconformity separates the steeply dipping foresets from flat-lying topset beds composed of poorly sorted, matrix-supported cobble gravels. Crude stratification is recorded by cobble lags, abrupt textural changes and shallow scours. At two locations, ice-wedge pseudomorphs up to $2 \mathrm{~m}$ deep and $0.6 \mathrm{~m}$ across intrude into the bedding in the upper gravel beds.

No major extensional faulting is present within the sediment sequence. The frontal slopes of the landform are subparallel $\left(25-30^{\circ}\right)$ to the foreset dips $\left(20^{\circ}\right)$.

\section{Interpretation}

The deposit's structure is similar to a Gilbert-type delta that prograded north-eastward into an extraglacial lake in the area of the present-day Benedy Glen valley. The rock-cut Altnasheskin meltwater channel acted as the main debris supply route from an ice lobe situated to the south-west of the local watershed between the Teeavan and Tamniarin Hills. Delta formation began with lake level at $245 \mathrm{~m}$ ASL, but a drop in lake level resulted in incision and erosion of the upper delta surface and formation of a lower, more extensive delta at $230 \mathrm{~m}$ ASL.

There is no evidence to suggest that ice directly fronting the delta in the Benedy Glen was responsible for water ponding, i.e. that pro-delta slopes were in ice contact. The lack of post-depositional extensional faulting in the delta-front facies indicates that the steep pro-delta slopes are probably primarily depositional, reflecting the internal steeply dipping foreset bed geometry.

The free-standing water body into which the Murnies deltas aggraded could have been formed by either a localised ice-marginal water body impounded against the rising bedrock slopes of 


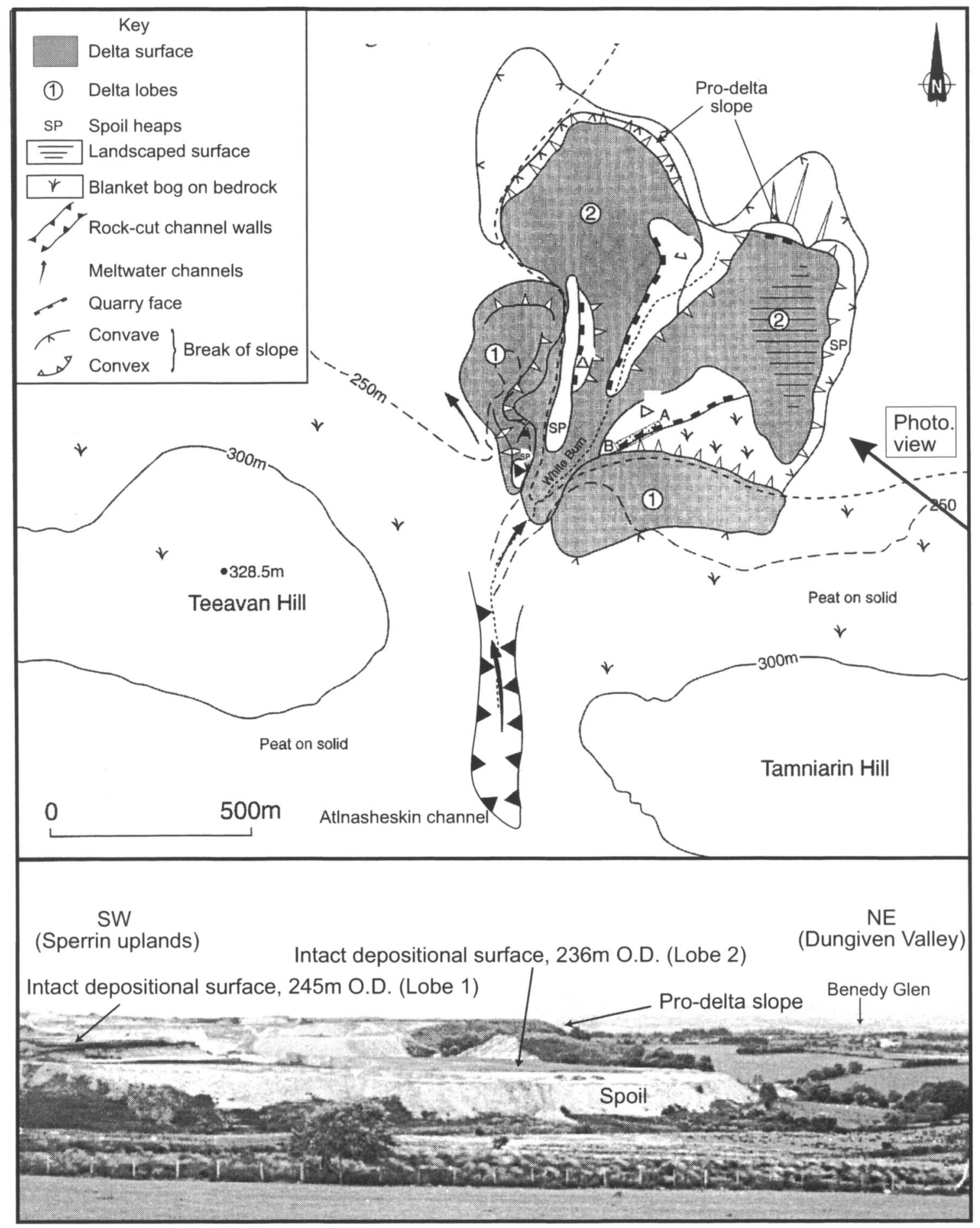

Fig. 12-Murnies delta overview, Benedy Glen, Dungiven Basin.

Teeavan Hill and an ice margin located downslope in the central Benedy Glen or a larger water body infilling the Benedy Glen and impounded by ice at the mouth of the valley at its junction with the Dungiven Depression, $2 \mathrm{~km}$ to the north. The lack of distinct moraines in the lower Benedy Glen possibly 
supports the latter explanation; however, no unequivocal evidence is reported to differentiate between the mechanisms.

\section{Banagher}

In the Owenrigh Valley, in the northern foothills of the main Sperrin Mountains range, a $1.2 \mathrm{~km}^{2}$ dissected spread of gravelly sand and poorly sorted massive cobble gravel occurs at the mouth of the valley along the southern margin of the Dungiven outwash plain (Fig. 4). Post-depositional meltwater erosion along the steep-sided, up-to-80m-deep Owenrigh Valley channel, which is cut in metamorphic bedrock, has bisected the sediments into two fragments. Flat tops (at $\sim 122 \mathrm{~m} \mathrm{ASL}$ ) on the fragments slope to the north-east and north-west, away from the channel mouth and the rising slopes of the Sperrins respectively.

The larger (Banagher Church) fragment is perched on the north-west slopes of Teeavan Hill, on the eastern flank of the Owenrigh channel. The deposit is up to $60 \mathrm{~m}$ thick and consists of stacked, massive, bimodal boulder-gravel beds dipping generally at $18^{\circ}$ to the north-east. At the elevation of its upper surface, a sharp-crested, sinuous, valleyparallel ridge $(0.5 \mathrm{~km}$ long $)$ trending north-west/ south-east terminates in a belt of hummocky morainic topography at the southern (up-valley) margins of the deposit. The belt is bordered on its inside (upslope) flank by the flat-topped beginnings of the Banagher fragment and the intake of a driftcut meltwater channel that falls north-eastward along the margins of the Banagher flat-topped fragment.

A small screed exposure in the $<40$ m-thick (Rallagh) fragment across the valley shows northdipping, trough-cross-stratified, well-sorted medium sand in channels. Both fragments have steep-sloped margins facing the Owenrigh channel that appear to be partly erosional.

\section{Interpretation}

The hummocky topography and sinuous ridge on the southern margins of the Banagher Church fragment and the poorly sorted boulder-gravel composition of the deposit suggest ice-marginal sediment supply from sources supplying sediment directly into a proglacial lake. Steeply dipping foresets probably resulted from the rapid deposition of coarse-gravel components as an ice-proximal node followed by avalanching of succeeding input down the lee-side slopes, with lateral dispersion of the sand and pebble-gravel component as subaqueous turbidity and traction currents. The foreset elevations at Banagher Church indicate deposition of a subaqueous spread into ponded water of at least $122 \mathrm{~m}$ ASL from an ice margin in the Owenrigh Valley. Post-depositional meltwater flow along the Owenrigh channel has bisected the delta into the two fragments observed.

Deposition must have occurred into a lake formed in the direction of the upper Roe Valley from an ice margin retreating south toward the Sperrins along the Owenrigh Valley. Because the Roe Valley opens northward toward the Lough Foyle Estuary, a temporary ponding mechanism must be envisaged in the topographic low of the valley. From the deposit's association with icemarginal sedimentation and continued proglacial subaqueous sedimentation in the direction of ice retreat (Templemoyle complex, $2 \mathrm{~km}$ up-valley), it is inferred that the ponding mechanism remained in place during ice-marginal retreat south into the Sperrins.

The ice-contact nature of the Banagher delta and undeformed up-valley accumulations at Templemoyle indicate that the valley was continually deglaciated to the south after deposition of the Banagher delta. The deltas thus decrease in age upslope. The Banagher delta is therefore not a product of the post-depositional erosion of the higher delta, and water levels rose in the valley as deglaciation proceeded south along it. Mechanisms for the impoundment of a proglacial water body in the lower Owenrigh Valley at $120 \mathrm{~m}$ ASL (the elevation of the Banagher delta) and then $230 \mathrm{~m}$ ASL (the elevation of the Templemoyle delta) are twofold: (1) the sediment bodies may have formed in a series of localised ice-marginal water bodies impounded against the rising slopes of the Sperrin Mountains by an ice margin located along the eastwest trend of the Dungiven Depression; (2) a large ( $\sim 200 \mathrm{~km}^{2}$ at maximum extent) proglacial lake may have formed during the deglacial period to the north of the Sperrin Mountains. The elevation of deltaic topset sedimentation may represent a rising lake level and periodic stasis of the ice margins in the valleys of the Sperrin Mountains as they actively retreated generally southward.

The available sedimentary and morphological evidence does not unequivocally differentiate between the localised and regional-scale ponding mechanisms. However, the absence of significantly entrenched overflow channels to the north and the pragmatic difficulty of sustaining a continually 
rising water body of such regional proportions seem to support a localised ponding mechanism. In addition, the evidence presented for ice-mass presence in the Dungiven Depression at some stage during the deglaciation (resulting in the deposits of the Derrynaflaw Formation) also supports a localised mechanism for water-body impoundment.

\section{Templemoyle}

At $\sim 2 \mathrm{~km}$ to the south of and up-valley from the deltaic topography at Banagher, a $0.75 \mathrm{~km}^{2}$ dissected deposit of flat-topped valley-fill remnants occurs to the south-west of Teeavan Hill (Fig. 4). Dissection has resulted in three perched, flat-topped fragments of similar elevation on opposing valley sidewalls. The fragments are separated by steep-sided rock-cut meltwater channels now occupied by the Cushcapal Water, the Glenedra Water and the Altnaheglish River, which form tributaries to the steep-sided, flat-bottomed channel occupied by the Owenrigh River. An exposure exists in the crest of the central flat-topped plateau remnant, comprising crossbedded medium sand and pebble-gravel foresets dipping generally north (down-valley) at $20-25^{\circ}$. Foreset heights reach $200 \mathrm{~m}$ ASL. Laterally, the deposit feathers against the rising slopes of the surrounding hills (Streeve Mountain, Teeavan Hill) or is truncated by small north-draining meltwater channels. To the south, small-scale (locally 5-8mhigh), dissected, hummocky topography extends in a thinning wedge for $\sim 1 \mathrm{~km}$ up-valley. The course of the misfit Finglen River now occupies a channel diverted by the southern extent of the hummocky deposits.

\section{Interpretation}

The foreset dips indicate ice-frontal retreat generally southward toward the Sperrin Mountains, with glaciofluvial sediments from this direction passing into a water body ponded in the Owenrigh bedrock depression at $\sim 200 \mathrm{~m}$ ASL. Meltwater erosion has resulted in dissection of the once flat-topped Gilbert-type delta and flushed out possible bottomsets infilling the Owenrigh Valley. The hummocky deposits to the southern, ice-proximal margin of the delta possibly comprise subglacial esker-type sediments formed along feeder channels that supplied debris to the valley-glacier ice margin. Alternatively, they may represent deglacial ice-marginal morainic accumulations formed as the ice margin retreated south. The preservation of depositional, flat-topped topography suggests that the deposit was not over-ridden by a post-depositional ice-marginal readvance and thus post-dates the ice-proximal sediments at Banagher.

\section{Mullaghash}

A perched, poorly exposed, flat-topped, steep-sided sand and gravel body is located $0.5 \mathrm{~km}$ south-west of the Finglen channel, on the north-eastern slopes of Mullaghash Mountain (Fig. 4). The flat top occurs at $\sim 260 \mathrm{~m}$ ASL. The deposit passes vertically down and laterally into diamict. This is separated from the hummocky deposits that form part of the Templemoyle complex by a meltwater channel occupied by the Owenbeg River.

\section{Interpretation}

It is inferred from the flat-topped, steep-sided morphology of the deposit that it probably constitutes a Gilbert-type delta formed at an ice margin retreating south-west into the Sperrin Mountains. It is inferred from the relatively high elevation of the necessary water-body surface (260m ASL) that an ice margin located in the lower Owenbeg Valley and the upper Owenrigh Valley impounded a localised ice-marginal lake in the upper Owenbeg Valley, into which the delta prograded. No firm evidence of the relative chronology of the Mullaghash, Banagher and Templemoyle deposits, which all occur within the same drainage basin, is present. However, from the relative heights of the local ice margins at the mouth of the Owenbeg River during formation of the Mullaghash delta $(\sim 50-60 \mathrm{~m})$, it is inferred that deposition occurred during formation of the Banagher deposit. At this time, ice was extensive enough to occupy the lower reaches of the Owenrigh channel.

\section{Altbritain}

A dissected and largely eroded valley fill occurs in the lower portions of the Altbritain River Valley at $\sim 350 \mathrm{~m}$ ASL (Fig. 4). The poorly exposed, flattopped valley-side remnants taper up-valley. Small exposures in streamsides in the thicker (up-to-30mhigh), down-valley fragments consist of parallellaminated interbedded fine sand, silt and mud containing occasional isolated pebble and cobble clasts (Fig. 13).

\section{Interpretation}

Exposed interbedded, parallel-laminated sand, silt and mud facies are interpreted as rhythmites deposited by quasi-continuous traction underflows 

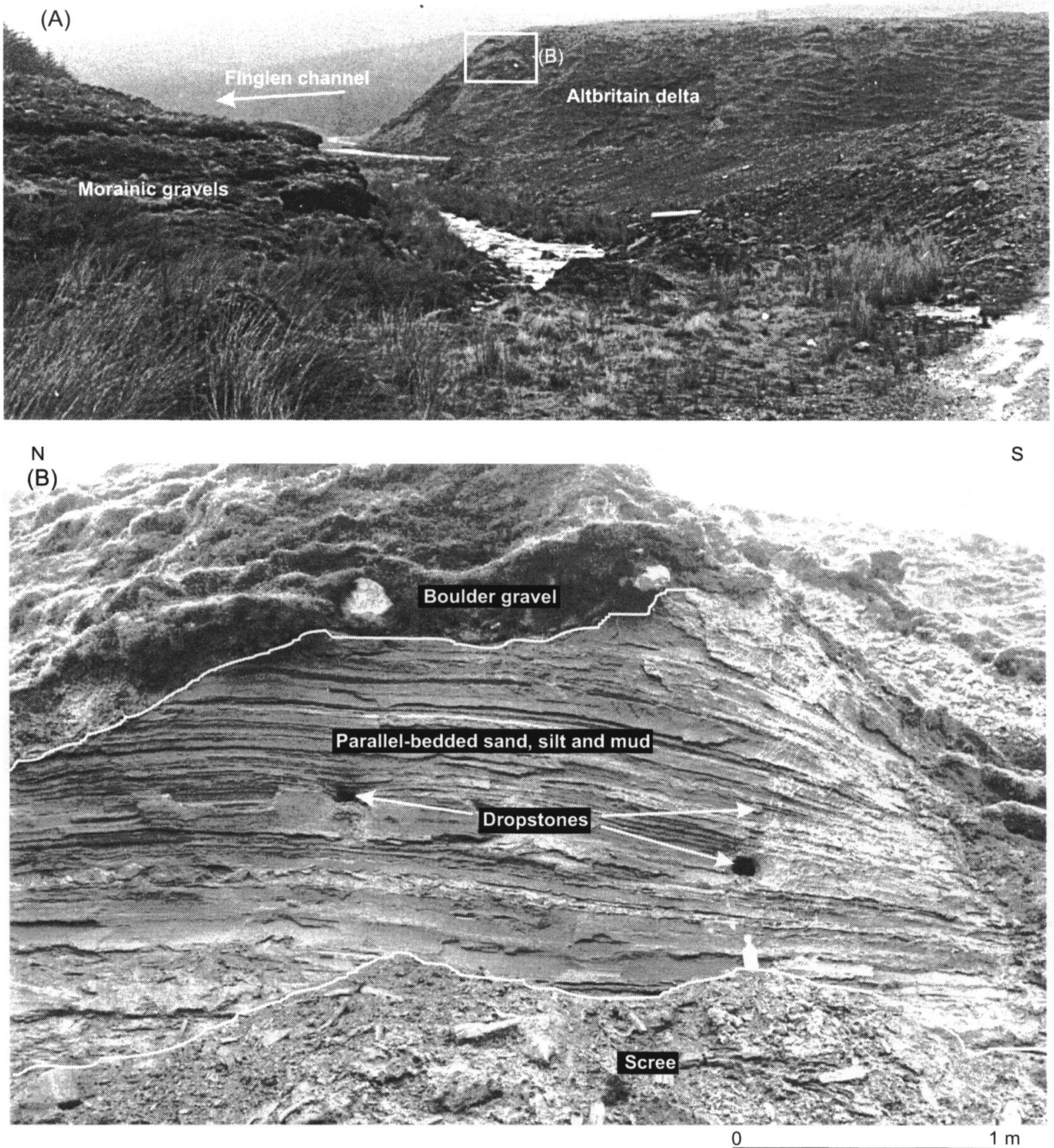

Fig. 13-Altbritain delta, Dungiven Basin. (A) Panoramic, down-valley (northward) view of Altbritain Valley. The dissected valley-side remnant is on the right-hand side of image. A small ridge of coarse, poorly sorted (morainic) gravels is shown in the left foreground. Finglen channel is in the middle distance, draining north-westward. Brown Hill is in the far distance. (B) Detail of parallel-laminated, interbedded sand, silt and mud comprising distal portions of the Altbritain delta. Near-crest location of image shown in (A).

(sand) and suspension rain-out (silt and mud). Occasional cobble-sized clasts were probably released as ice-rafted debris. The sediments described therefore comprise ice-distal facies, deposited into a proglacial water body of considerable depth. The coarse gravel exposed at the crest of the ridge may 
represent topset beds formed as the deltaic wedge aggraded to water-body elevation. The sediment facies and flat-topped geometry of the deposit indicate that the deposit represents a subaqueous fan deposited into an ice-marginal water body impounded in the Altbritain Valley from a sediment source to the south, in the direction of the upper Sperrin Mountains (Fig. 15). At this elevation, the probable impounding mechanism was an ice margin occupying lower ground (the upper Finglen channel) to the north.

\section{Tamnagh}

At Dreen (Fig. 4), a complex of poorly exposed, dissected cross-valley ridges forms several topographic highs (locally 10-15m) interspersed with flat-topped alluvial terraces.

At $\sim 3 \mathrm{~km}$ up-valley, on the north-western slopes of Learmount Mountain, a steep-sided ridge of bimodal planar-cross-bedded sand and cobble gravel occurs perched on the valley side. Exposed beds dip at $25^{\circ}$ to $120^{\circ} \mathrm{N}$. Directly across-valley, $9 \mathrm{~m}$ of stratified sediments is exposed in a remnant wedge of formerly more extensive valley fill. A composite exposure of the ridge and valley fill consists of six main lithofacies (Fig. 14). The lowest lithofacies exposed (G1) consists of $1 \mathrm{~m}$ of low-angle (dipping at $10^{\circ}$ to $100^{\circ} \mathrm{N}$ ), planar-bedded cobble to pebble gravel. This is conformably overlain by $5 \mathrm{~m}$ of stacked diamicts (D1) interbedded with $(<15 \mathrm{~cm}$ thick) discontinuous cobble-gravel beds, boulders and silt stringers. The third lithofacies consists of $0.8 \mathrm{~m}$ of deformed massive fine sand (S1). The fourth lithofacies comprises $1.6 \mathrm{~m}$ of planar-bedded $(<10 \mathrm{~cm})$ medium sand $(\mathbf{S} 2)$ in conformable contact with S1. The fifth lithofacies consists of an unknown thickness of stacked massive cobble-gravel beds, cross-bedded sand and cobble gravel (G2). The sixth lithofacies, comprising stacked massive cobble gravel (G3), occurs inside an erosive channelmargin contact with G2. A $15 \mathrm{~m}$-high steep slope $\left(\sim 35^{\circ}\right)$ forms the southern extent of the ridge, composed of facies $\mathrm{G} 2$ and $\mathrm{G} 3$.

In the upper valley, $\sim 0.5 \mathrm{~km}$ farther south and at $30 \mathrm{~m}$ higher elevation, three distinct, steep-sided, subparallel beaded ridges, $\sim 20 \mathrm{~m}$ across and $15 \mathrm{~m}$ high, run $200 \mathrm{~m}$ cross-valley from a mound $30 \mathrm{~m}$ in
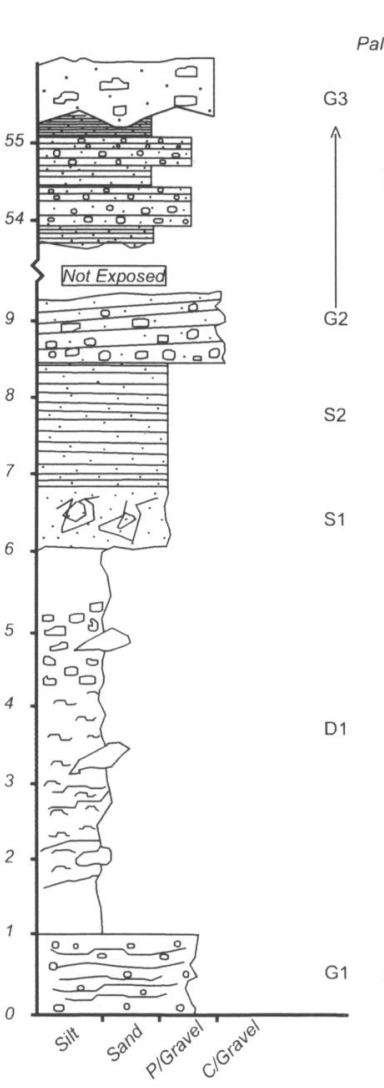

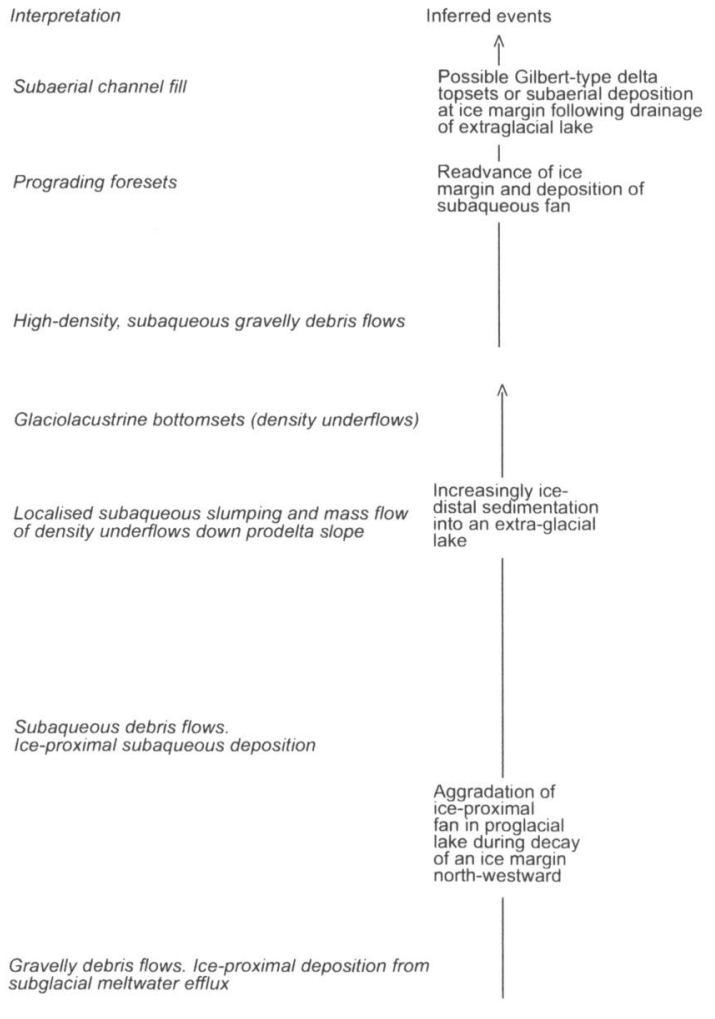

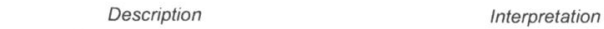

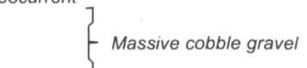

(1) Dip 25

Planar-cross-bedded sand and gravels

Stacked beds of massive cobble grave

Planar-bedded sand

Massive, deformed silt and sand (1)
Stacked, poorly defined diamicts with matrix-rich cobble beds; boulders

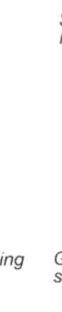
Stacked massive beds of shallow-dipping
planar cobble and pebble gravel

Fig. 14-Measured log of Tamnagh Valley infill, Dreen, Dungiven Basin. 
diameter located $40 \mathrm{~m}$ above the ridge tops. A smallscale $(10 \mathrm{~m}-$ by $-2.5 \mathrm{~m})$ exposure in one cross-valley ridge shows stacked, conformably bedded, troughand planar-cross-bedded sets of sands and poorly sorted cobble gravels. Sharp, subvertical, sinuous erosional contacts separate geometrically, but not texturally, similar sets. The cross-bedded units dip at $15^{\circ}$ to $40^{\circ} \mathrm{N}$, subparallel to the long axis of the ridge.

\section{Interpretation}

The Tamnagh Valley is interpreted as containing a complex of cross-valley moraines, deltaic valley fill and eskers. The section detailed is interpreted as representing part of a glaciolacustrine valley fill. Facies S1 to G2 represent the foresets of a glaciolacustrine delta prograding to $120^{\circ} \mathrm{N}$ into a water body ponded in the valley at $256 \mathrm{~m}$ ASL. The steep slope to the south of the deposit was possibly ice contact and represents the ice-front position at the time of the delta's progradation.

The poor exposure of the features in the upper valley leaves interpretation based largely on morphology. The small-scale bedding structures and sharp, vertical erosional contacts (interpreted as representing rapid, channelised, cross-cutting avulsion) lead to the interpretation of the slopes as primarily depositional in character and the linear features as esker fragments.

\section{Interpretation of the Banagher Morphostratigraphic Unit}

The sediments of the Banagher Unit are predominately indicative of subaqueous deposition in ice-marginal locations related to topographically controlled retreat of ice margins generally south and south-east into the higher regions of the Sperrins. Source regions for these valley or outlet glaciers may have been the local catchment area of the upper Sperrins (outlets from independent plateau-type ice fields) or outlets from the major ice-dispersal centre located in the lowlands of the Lough Neagh Basin (McCabe et al. 1999), or some combination of the two (Fig. 15). The topographic barrier presented by the south-eastern margin of the Sperrins, together with the reconstructed relative chronology of early deglaciation onset represented by the Banagher Unit, supports the former explanation.

The lack of topographic barriers in the direction of consistent palaeoflow (south to north) suggests that deposition occurred into temporary water bodies. Several of the deposits in the unit (the
Banagher and Templemoyle deltas in the Owenbeg Valley) are critical in defining the events that characterised the deglaciation of the northern flanks of the Sperrins. The deltas indicate a pattern of stepwise, south-rising glaciodeltaic infill of the valley channel, implying that ice retreat occurred as a set of retreat and ice-marginal still-stand phases. This retreat was contemporaneous with the presence of a deepening proglacial water body in the valley. The suggested mechanism for this occurrence is an ice dam down-valley that would have (1) allowed the formation of lateral overflow channels to control water-body elevation and (2) increased in elevation between the phases of ice-marginal recession up-valley, impounding water at $122 \mathrm{~m}$ ASL (Banagher) and later at 200m ASL (Templemoyle).

Thus, to allow for the observed spatial and temporal patterns of sedimentation, the water bodies are inferred to have been impounded in the north-facing valleys of the Sperrins by an ice mass occupying the east-west axis of the Dungiven Depression (Fig. 15). This is inferred to be the same ice mass that gave rise to the deposits of the Derrynaflaw Unit during its retreat south-west along the axis of the Dungiven Depression. In this regard, it is considered unnecessary to invoke the impoundment of a water body to elevations of $200 \mathrm{~m}$ ASL along the entirety of the Roe Valley as far north as the southern margins of Lough Foyle.

The efflux of glacial drainage into these localised ponded water bodies took a variety of forms (icemarginal and paraglacial) at different locations, resulting in sedimentologically and morphologically different deposits and field associations (some with eskers and morainic gravels associated, e.g. Banagher delta, and some fed by rock-cut meltwater channels, e.g. Murnies delta). Many more landforms of similar genesis may have been removed postglacially following drainage of the temporary lakes after down- and back-wasting of ice masses occupying the Dungiven Depression (during deposition of the Derrynaflaw Unit). The subaerial exposure of perched, unconsolidated sediments and the continued supply of large meltwater volumes as lake levels dropped resulted in deep dissection and reworking of the deposits, probably giving rise to the extensive outwash gravel spreads infilling the lower reaches of the Faughan Valley and the Roe Valley.

From correlation of the Banagher Unit (related to ice flow from the Lough Neagh Basin) and the Derrynaflaw Unit (related to ice flow from Donegal), it is inferred that the margins of Lough Neagh ice began to retreat into the valleys of the Sperrins 


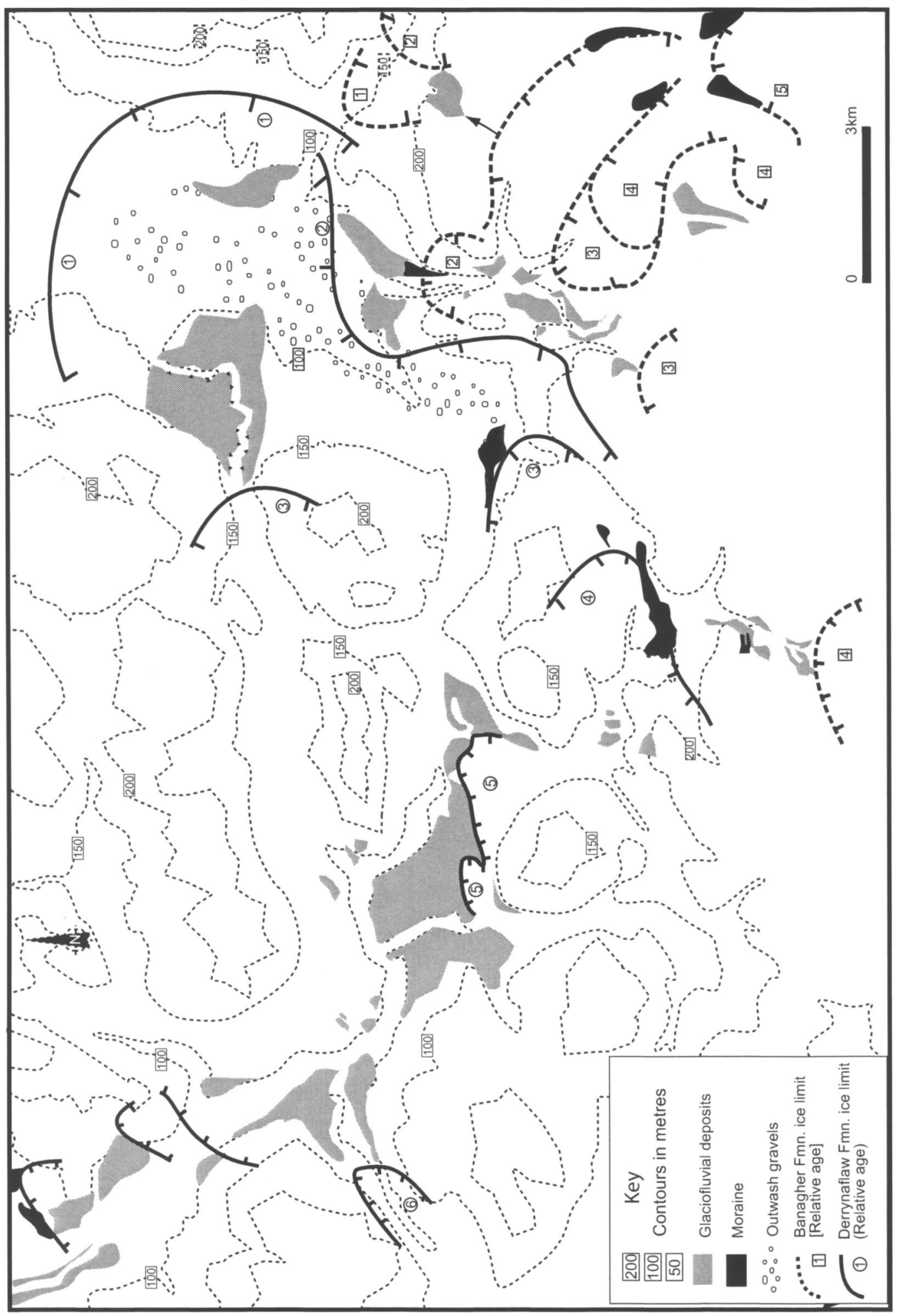

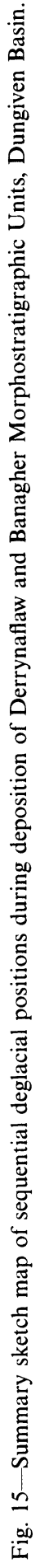


before deglaciation of the Dungiven Depression was under way. It is thus inferred that the margins of outlet glaciers in the northern Sperrins sourced from ice-dispersal centres located in the Lough Neagh Basin were initially more responsive to the climatic amelioration associated with the initial stages of Termination 1. This may have been due to:

1. their hypsometry as valley-fill outlet glaciers with relatively extensive margins at low elevations and/or

2. down-wasting of the ice sheet across the higher topographic barrier of the southwest Sperrins ( $>400 \mathrm{~m} \mathrm{ASL}$ ), with eventual removal of outlet glacier ice supply resulting in a late phase of isolated valley glaciation.

Deglaciation was not continuous, however, and may have been punctuated with periods of relatively reduced ice-marginal retreat rates due to periods of ice-mass positive mass balance and rejuvenation. This was possibly due to the relatively high-altitude locations of the ice masses and/or additional ice supply from local high-altitude plateaus, e.g. upper Glenshane.

\section{Discussion}

The Dungiven Basin is an area influenced by the glacial dynamics associated with multiple sectors of the last British-Irish Ice Sheet. It may thus form an area within which evidence of the development and decay phasing relationships between these sectors may be evaluated.

The distribution of relatively well-preserved, topographically prominent, relict glaciofluvial and ice-marginal landforms, including flat-topped Gilberttype deltas, outwash spreads, eskers and hummocky moraine, attributable to the last deglaciation of the Dungiven Basin indicates a complex pattern of ice-marginal interaction with local topography during retreat and subsequent water-body impoundment during that period. Deglacial ice-marginal positions rise toward higher ground to both the west and the south-east. Interpreted as a west- and south-east-younging sequence, the landform pattern indicates glaciation of the basin during the late Devensian by ice masses sourced from centres of ice dispersal in the south Donegal Highlands (Blue Stack Mountains) and the Lough Neagh Basin. The model combines ice supply from Donegal into the upper and middle reaches of the Faughan Valley and the Foyle Basin and glaciation of the south-east corner of the Dungiven Basin by ice extending north-east from the Lough Neagh Basin. No deposits of the relict glaciofluvial system show evidence of overriding, and they are thus assigned a late Midlandian age. The two areas have been well documented as areas of ice dispersal during this last cold period (Ballantyne et al. 2007; Charlesworth 1924; Dardis 1980; Knight 1997; Knight and McCabe 1997a; 1997b; Greenwood and Clark 2009).

\section{Deglaciation of the Dungiven Basin}

The Derrynaflaw Unit comprises the glaciolaustrine and associated landforms occurring in the upper Roe and Faughan Valleys. Deposition of the landforms and their reworking are related to ice-marginal retreat generally toward the south-west and west, toward Donegal, in the presence of ice-marginal and extra-glacial water bodies. The Banagher Unit consists of glaciolacustrine and associated landforms located in the northern valleys and flanks of the Sperrin Mountains. The deposits are related to sediment and meltwater supply from the south and south-east. Ice-marginal retreat was in this direction during the impoundment of glacial lakes in topographic valleys and along the northern flanks of the Sperrin Mountains.

Ice-marginal positions are recorded in the suite of ice-marginal and extra-glacial landforms retreating west and south-east from the basin (Fig. 15). Interpreted as a west- and south-east-younging sequence, the landform pattern indicates glaciation of the basin during the late Devensian by ice masses sourced from centres of ice dispersal (ice-sheet domes) in south Donegal and the Lough Neagh Basin, supporting the south-migrating ice-dispersal centre and progressively eastward (-veering) ice-flow pattern during deglaciation (Greenwood and Clark 2009).

Ice flow extending from central and southeastern Donegal along the Foyle Valley and into the Foyle Basin/Estuary is thought to have been a significant feature of the late LGM and early deglacial period in the region. This is based on the pattern of inferred later-stage ice flow into the Foyle Basin (Greenwood and Clark 2009, fs40) and the generally west-retreating ice-marginal positions along the eastern fringes of the Foyle Valley recorded here (Derrynaflaw Unit) and in Charlesworth (1924).

It is thus inferred that glaciation of the Foyle Estuary and the Dungiven Basin was by ice from the west and south-west and that it persisted during 
deglaciation of the hill and valley terrain of the northern flank of the Sperrins. Ice in these valleys was actively deglaciating toward source areas in the direction of the higher Sperrins and/or the Lough Neagh Basin (cf. Greenwood and Clark 2009, fs50c).

The impoundment mechanism of the lower Roe Valley, giving rise to the landforms of the Derrynaflaw Unit, is thus interpreted to have been a lobe of ice sourced from the west (Donegal), not a surge event of Scottish ice across the North Channel and Malin Sea (McCabe et al. 1998). The phasing relationship between the presence of ice in the Foyle Basin and the advance of Scottish ice into the Bann Valley lowlands forming the Armoy moraine (McCarron 2000) is not directly constrained to date.

\section{Deglacial water-body impoundment within the Dungiven Basin}

In the Dungiven Basin, glaciodeltaic deposits of the Derrynaflaw Unit aggraded in water bodies ponded above the altitude of current free-drainage routes to the north, requiring a proglacial water-ponding mechanism. Two opposing models exist for the mechanism of water-body impoundment allowing the formation of these deposits. Charlesworth (1924) envisaged a set of topographically controlled, localised water bodies. McCabe et al. (1998) postulated water-body impoundment by a readvance of Scottish ice into the Foyle Basin from the east, blocking the drainage escape route of the Foyle Estuary.

However, neither of these two models is thought to account fully for the evidence presented here. It is argued that mechanisms of water-body impoundment were multiple but centred on the interplay between deglaciating ice masses on the flanks of the Sperrin Mountains and in the topographic depressions of the Foyle Estuary and the Faughan Valley. It is inferred in this model that glaciation of the Foyle Basin by ice from the west and south-west persisted during initial deglaciation of the Dungiven Depression (Derrynaflaw Unit). Several processes may explain any difference in the timing and/or rate of deglaciation in the two areas:

1. Ice-flow paths. If processes of down-wasting were significant during deglaciation, the south-western corner of the Sperrins (along the line of the Slievekirk-Learmount mountain ridge) would have created a significant topographic barrier for northeastward ice flow into the basin. Ice flow from a north-south-oriented ice divide over
Donegal (as reconstructed by all workers from Close 1866 onwards; cf. Greenwood and Clark 2009) into and northward along the Foyle Valley would, however, have had a relatively unimpeded downhill path along the wide topographic low of the Finn/Foyle Valley system into the Foyle Basin.

2. Differences in ice-sheet sector activity. Ice from central Donegal was thought to have been involved in two phases of ice advance toward the south-west during the last Termination (Knight and McCabe 1997a), which may have weakened east-directed flow strengths. Advance into and along Donegal Bay at $27 \mathrm{ka}$ BP was followed by deglaciation and ice-free conditions within the embayment (McCabe et al. 2007b). At $\sim 20$ cal. ka BP, a more restricted readvance of this margin into the bay was followed by marine down-draw processes toward tidewater margins in the bay, during which the final 'drumlin-shaping' event occurred inland (McCabe et al. 1992). Icesheet down-draw processes (Hughes 1986) are modelled as propagating inland and accelerating ice flow across southern Donegal and the Lough Erne Basin. One of the principal effects of large-scale ice-flow acceleration is modelled to involve a progressive flattening of the ice-sheet profile up-ice and thus a progressive reduction in ice pressure toward other (inland) margins, e.g. in the direction of the Dungiven Basin. Similarly, Knight (1997; 2003) documented shifts in the location of the ice divide in the Omagh Basin (eastward toward the Fintona Hills) and down-draw of the ice-sheet profile as ice flowed west toward Donegal Bay margins.

\section{Conclusions}

It is argued that glaciation of the Foyle Basin by ice of Scottish origin during overall deglaciation of the last British-Irish Ice Sheet (McCabe et al. 1998) is not required to account for the glaciolacustrine landforms in the Dungiven Basin, north-west Ireland. Patterns of ice-marginal decay as shown by reconstructed morphostratigraphic units, support final deglaciation of the Foyle Basin and the Dungiven Basin by ice retreating toward source areas to the south-west. It is proposed that the spatial interplay between these ice margins and bedrock topography 
during deglaciation provides plausible local mechanisms for water-body impoundment.

Whether deglaciation of the Dungiven Basin was continuous or was interrupted by a prolonged period of ice-marginal stabilisation or even readvance remains unresolved. It is possible that the aggradation of so many substantial sand and gravel deposits in the basin was related to ice-sheet events associated with Heinrich Event 1, at $~ 17.5 \mathrm{ka}$ BP (McCabe et al. 1998; McCabe and Clark 1998). In the absence of geochronological constraint, however, it is very difficult to establish such correlations.

Currently, the pattern of ice-marginal recession may indicate sectoral mass-balance difference (e.g. highland source areas continuing to receive sustaining precipitation volumes) and/or variations in iceflow 'strength' (possibly owing to reductions in icesheet vertical profiles due to down-draw elsewhere). The ice-flow patterns presented here do, however, provide more resolution to support models of a highly dynamic last British-Irish Ice Sheet (McCabe 1985). Reconstructions of ice-sheet initiation and development on realistic terrain, at high temporal resolution and driven by inferred palaeoclimatic variables (e.g. Hubbard et al. 2009), indicate that highly dynamic ice-sheet growth and decay cycles may have occurred repeatedly within a 'glaciation'. To achieve confidence in the capture of ice-sheet scale-growth, motion and decay processes with these models, the strongest set of geological evidence is needed to evaluate the input parameter sets. This highlights the importance of continuing to evaluate critically and possibly refine the geological record of former ice growth and decay in Ireland.

\section{Acknowledgements}

Thanks are extended to Dr Jasper Knight for constructive criticism of the script and discussion over many years. This work was funded by the Department of the Environment (Northern Ireland) (1993-7), with the support of Mr Ian Enlander, and by the School of Environmental Studies, University of Ulster, as part of the author's DPhil studies (1997-2000), with the support of Professor David Eastwood. Above all, the tuition, guidance and friendship of Professor A. Marshall McCabe over the last two decades are most gratefully acknowledged. None of this work or any since would have been possible without his unstinting help and support.

\section{References}

Ballantyne, C.K., McCarroll,' D. and Stone, J.O. 2007 The Donegal ice dome, northwest Ireland, dimensions and chronology. Journal of Quaternary Science 22 (8), 773-83.

Bazley, R.A.B., Brandon, A. and Arthurs, J.W. 1997 Geology of the country around Limavady and Londonderry. Geological Survey of Northern Ireland Technical Report GSNI/97/1. Belfast. Geological Survey of Northern Ireland.

Boulton, G.S., Smith, G.D., Jones, A.S. and Newsome, J. 1985 Glacial geology and glaciology of the last mid-latitude ice sheets. Journal of the Geological Society 142, 447-74.

Bowen, D.Q., Rose, J., McCabe, A.M. and Sutherland, D.G. 1986 Correlation of Quaternary glaciations in England, Ireland, Scotland and Wales. Quaternary Science Reviews 5, 299-340.

Charlesworth, J.K. 1924 The glacial geology of the north-west of Ireland. Proceedings of the Royal Irish Academy 36B, 174-314.

Charlesworth, J.K. 1939 Some observations on the glaciation of the north-east of Ireland. Proceedings of the Royal Irish Academy 45B, 255-92.

Chiverrell, R.C. and Thomas, G.S.P. 2010 Extent and timing of the Last Glacial Maximum (LGM) in Britain and Ireland: a review. Journal of Quaternary Science 25 (4), 535-49.

Clark, J., McCabe, A.M., Bowen, D.Q. and Clark, P.U. 2012 Response of the Irish Ice Sheet to abrupt climate change during the last deglaciation. Quaternary Science Reviews 35 (1), 100-15.

Close, M.H. 1866 Notes on the general glaciation of Ireland. Journal of the Royal Geographical Society of Ireland 1, 207-42.

Colhoun, E.A. 1970 On the nature of the glaciations and final deglaciation of the Sperrin Mountains and adjacent areas in the north of Ireland. Irish Geography 6, 2162-85.

Colhoun, E.A. 1971 The glacial stratigraphy of the Sperrin Mountains and its relation to the glacial stratigraphy of north-west Ireland. Proceedings of the Royal Irish Academy 71B (2), 2-52.

Creighton, J.R. 1974 A study of the late Pleistocene geomorphology of north central Ulster. Unpublished PhD thesis, Queen's University Belfast.

Dardis, G.F. 1980 Field Guide no. 3: Co. Tyrone, Northern Ireland. Birmingham. Irish Quaternary Association.

Dawson, M.L. and Gardiner, V. 1987 River terraces: the general model and a palaeohydrological and sedimentological interpretation of the terraces of the lower Severn. In K.J. Gregory, J. Lewin and J.B. Thomas (eds), Hydrology in practice, 269305. New York. Wiley.

Dwerryhouse, A.R. 1923 The glaciation of north-eastern Ireland. Quarterly Journal of the Geological Society 79, 353-421.

Greenwood, S.L. and Clark, C.D. 2009 Reconstructing the last Irish Ice Sheet 1: changing flow geometries and ice flow dynamics deciphered from the glacial landform record. Quaternary Science Reviews 28 (27-8), 3085-100.

Hubbard, A., Bradwell, T., Golledge, N., Hall, A., Patton, H., Sugden, D., Cooper, R. and Stoker, M. 2009 Dynamic cycles, ice streams and their impact on the extent, chronology and deglaciation of the British-Irish Ice Sheet. Quaternary Science Reviews 28 (7-8), 758-76.

Hughes, T. 1986 The Jakobshavns effect. Geophysical Research Letters 13 (1), 46-8.

Hull, E. 1891 Physical geology and geography of Ireland, 2nd edn. London. E. Stanford. 
Jopling, A.V. and Walker, R.G. 1968 Morphology and origin of ripple drift cross-lamination, with examples from the Pleistocene of Massachussetts. Journal of Sedimentary Petrology 38 (4), 971-84.

Kilroe, J.R. 1888 Directions of ice flow in the north of Ireland. Quarterly Journal of the Geological Society 44, 827-33.

Kilroe, J.R. 1913 Outline of geological observations in northeast Londonderry collected during the progress of revision work. Annual Report and Proceedings of the Belfast Naturalists' Field Club ser. 2 6, 634-63.

Knight, J. 1997 Ice readvance from the southern Sperrin Mountains during the last glaciations. Irish Journal of Earth Sciences 16, 61-9.

Knight, J. 2003 Geomorphic evidence for patterns of late Midlandian ice advance and retreat in the Omagh Basin Irish Geography 33 (1), 1-22.

Knight, J. and McCabe, A.M. 1997a Drumlin evolution and ice sheet oscillations along the NE Atlantic margin, Donegal Bay, western Ireland. Sedimentary Geology 111, 57-72.

Knight, J. and McCabe, A.M. 1997b Identification and significance of ice-flow-transverse subglacial ridges (Rogen moraines) in northern central Ireland. Journal of Quaternary Science 12 (6), 519-24.

Lukas, S. 2006 Morphostratigraphic principles in glacier reconstruction-a perspective from the British Younger Dryas. Progress in Physical Geography 30 (6), 719-36.

McCabe, A.M. 1985 Glacial geomorphology. In K.J. Edwards and W.P. Warren (eds), The Quaternary history of Ireland, 6793. London. Academic Press.

McCabe, A.M. 1987 Quaternary deposits and glacial stratigraphy in Ireland. Quaternary Science Reviews 6, 259-99.

McCabe, A.M. 1999 Ireland. In D.Q. Bowen (ed.), A revised correlation of Quaternary deposits in the British Isles, 115-24. Geological Society Special Report 23. Bath. Geological Society.

McCabe, A.M. and Clark, P.U. 1998 Ice-sheet variability around the North Atlantic Ocean during the last deglaciation. Nature 392, 373-7.

McCabe, A.M. and Clark, P.U. 2003 Deglacial chronology from County Donegal, Ireland: implications for deglaciation of the British-Irish Ice Sheet. Journal of the Geological Society 160, 847-55.

McCabe, A.M., Dardis, G.F. and Hanvey, P.M. 1992 Glacial sedimentology in northern and western Ireland: pre- and post-symposium field excursion guide book. Cambridge. Anglia Polytechnic.

\section{STEPHEN MCCARRON,}

Department of Geography,

National University of Ireland, Maynooth,

Maynooth,

Co. Kildare.

E-mail: Stephen.McCarron@nuim.ie
McCabe, A.M., Knight, J. and McCarron, S.G. 1998 Evidence for Heinrich Event 1 in the British Isles. Journal of Quaternary Science 13 (6), 549-68.

McCabe, A.M., Knight, J. and McCarron, S.G. 1999 Ice-flow stages and glacial bedforms in north central Ireland: a record of rapid environmental change during the last glacial termination. Journal of the Geological Society 156 (1), 63-72.

McCabe, A.M., Clark, P.U., Clark, J. and Dunlop, P. 2007a Radiocarbon constraints on readvances of the British-Irish Ice Sheet in the northern Irish Sea Basin during the last deglaciation. Quaternary Science Reviews 26 (9-10), 120411.

McCabe, A.M., Clark, P.U. and Clark, J. 2007b Radiocarbon constraints on the history of the western Irish ice sheet prior to the Last Glacial Maximum. Geological Society of America Bulletin 35 (2), 147-50.

McCarron, S.G. 2000 Late Devensian glaciation of the north of Ireland. Unpublished DPhil thesis, University of Ulster.

Miall, A.D. 1978 Lithofacies types and vertical profile models in braided river deposits: a summary. In A.D. Miall (ed.), Fluvial sedimentology, 597-604. Canadian Society of Petroleum Geologists Memoir 5. Calgary. Canadian Society of Petroleum Geologists.

Rust, B.R. 1988 Ice-proximal deposits of the Champlain Sea at South Gloucester, near Ottawa, Canada. In N.R. Gadd (ed.), The late Quaternary development of the Champlain Sea Basin, 37-46. Geological Association of Canada Special Publication 35. Ottawa. Geological Association of Canada.

Skinner, B.J. and Porter, S.C. 1987 Physical geology. Chichester, West Sussex. Wiley.

Stephens, N., Creighton, J.R. and Hannon, M.A. 1975 The late Pleistocene period in north-eastern Ireland: an assessment 1975. Irish Geography 8, 1-23.

Synge, F.M. and Stephens, N. 1960 The Quaternary period in Ireland: an assessment. Irish Geography 4 (2), 120-30.

Warren, W.P. 1992 Drumlin orientation and the pattern of glaciation in Ireland. Sveriges Geologiska Undersökning 81, 359-66.

Wilkinson, S.B., McHenry, A., Kilroe, J.R. and Seymour, H.J. 1908 The geology of the country around Londonderry. Memoirs of the Geological Society of Ireland. Dublin. HMSO.

Wilson, H.E. 1972 Regional geology of Northern Ireland. Belfast. HMSO. 